\title{
Distribution of Ore Deposits and Spectrographic Analyses of Some Rocks and Ores on the Colorado Plateau
}

By

Leonard B. Riley and Eugene N. Shoemaker

Trace Elements Investigations Report 278

UNITED STATES DEPARTMENT OF THE INTERIOR GEOLOGICAL SURVEY 
American Cyanamid Company, Winchester. . . . . . . . I

Argonne National Laboratory. . . . . . . . . . 2

Atomic Energy Commission, Washington ........... $3-4$

Battelle Memorial Institute, Columbus。.......... 5

Carbide and Carbon Chemicals Company, Y-12 Area. ..... 6

Grand Junction Operations Office . . . . . . . . 7

Exploration Division, Grand Junction Operations Office 。. 8 13

Division of Raw Materials, Grants. . . . . . . . . 14

Division of Raw Materials, Denver. . . . . . . . . 15

Division of Raw Materials, Hot Springs . . . . . . . 16

Division of Raw Materials, New York。......... $17-22$

Division of Raw Materials, Salt Lake City。 . . . . . 23

Division of Raw Materials, Richfield .......... 24

Division of Raw Materials, Butte . . . . . . . . 25

Division of Raw Materials, Washington......... $26-33$

Division of Research, Washington ........... 34

Dow Chemical Company, Pittsburg。 ............ 35

Technical Information Service, Oak Ridge . . . . . . 36-41

Tennessee Valley Authority, Wilson Dam .......... 42

U. S. Geological Survey:

Mineral Deposits Branch, Washington. ......... $43-44$

Geochemistry and Petrology Branch, Washington。..... $45-54$

Geophysics Branch, Washington。.......... 55

Alaskan Geology Branch, Washington .......... 56

Fuels Branch, Washington 。. . . . . . . 。 57

L。 R。 Page, Denver 。........... $58-59$

R。 P. Fischer, Grand Junction. . . . . .... 60 - 61

A. E。 Weissenborn, Spokane ........... . . 62

J。 B. Cathcart, Plant City ............. 63

J. Fo Smith, Jr。 Denver. . . . . . . . . . 64

N. M. Denson, Denver 。. 。 . . 。 。 。 . 65

R.W. Swanson, Spokane 。.................. 66

A. H。 Koschmann, Denver 。........... 67

E. H。 Bailey, San Francisco. ........... 68

C. E。 Dutton, Madison。 . . . . . . . . 69

R. A。 Laurence, Knoxville. . . . . . . . . 70

R。 Jo Roberts, Salt Lake City.............. 71

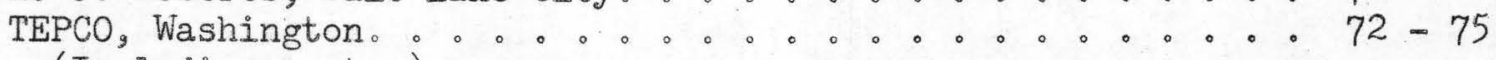
(Including master) 
CONTEENTS

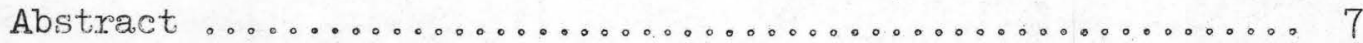

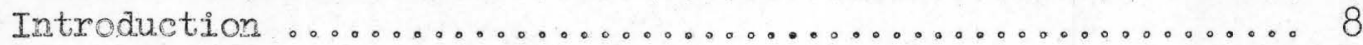

Geologic setting of the Colorado Plateau ............... 9

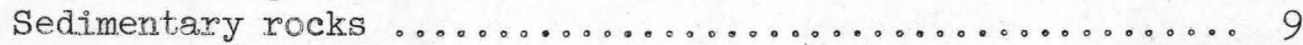

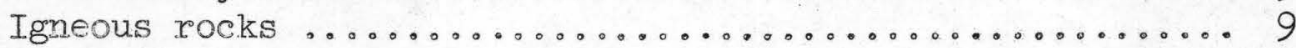

Types of cre deposits on the Colorado Plateau ............. 12

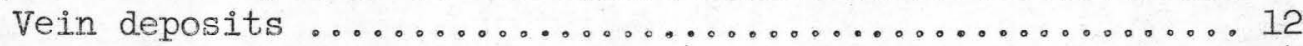

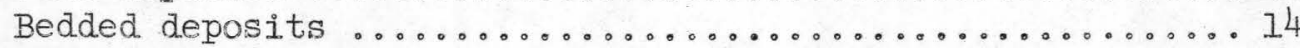

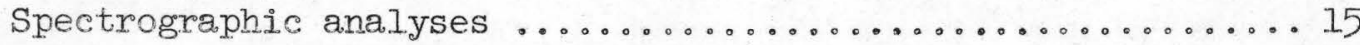

Sensitivity of the spectrographic method ............. 15

Group number method of reporting spectrographic analyses ...18

Average composition of rocks and ores ................. 8

Variation of metal content in bedded uranium ores .......20

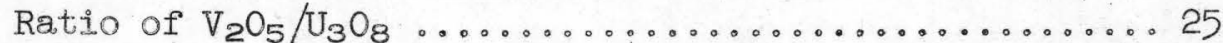

Elements largely contained in detrital minerals: titanium, chromium, zirconium, boron .............26 6

Metals of uncertain affinities: beryllium, arsenic,

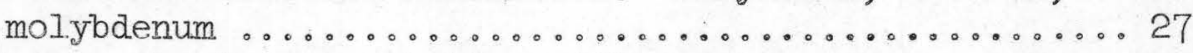

Metals showing correlation with uranium ore: copper, silver, cobalt, nickel, lead, zinc .............28

Possible guides to large ore deposits ............29

\section{ILIUSTRATION}

Page

Figure 1. Distribution histogram of average uranium assays of 59 mill-pulp samples ................... 24

\section{TABIES}

Page

Table 1. Generalized section of Pennsylvanian to Eocene strata in the north-central part of the Colorado Plateau

2. Chemical analyses of laccolithic and other intrusive rocks on the Colorado Plateau 


\section{TABIES}

Pa.ge

Table 3. Stratigraphic distribution of bedded metal

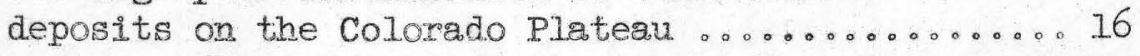

4. Threshold values of elements included in the semiquantitative method, with particular reference to materials analyzed from the Colorado Plateau ... 17

5. Average chemical composition of Sa.1t Wash mudstones and shales compared with the average compo-

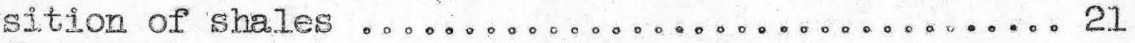

6. Avergge chemical composition of Salt Wash'sandstones compared with the average composition of

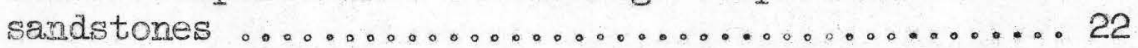

7. Average chemical composition of bedded uranium ore deposits from spectrographic analyses of 99 mill-

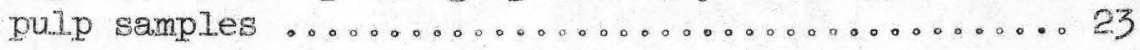

8. Spectrographic analyses of barren Salt Wash sand.stones

A. Colorado Iocalities: Horseshoe Bend and Tenderfoot Mesa ............................. 30

B. Colorado localities: Dolores group of mines, Club mine, and Ca.lamity No. 13 mine ........ 31

C. Colorado localities: Placerville and skein

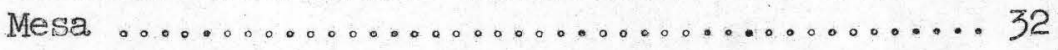

D. New Mexico and Utah 1ocalities ............. 33

9. Spectrographic analyses of heavy mineral fraction from barren Salt Wash sandstones ............. 34

10. Spectrographic analyses of barren Salt Wash mud-

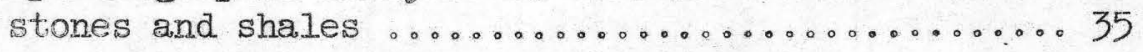

11. Spectrographic ana.1yses of intrusive igneous rocks on the Colorado Plateau. 
TABLES (cont。)

Page

Trable 11. A. Dioxite and monzonite porphyries from the

La SaI Mountains, Utah ................. 37

B. Syenite and granite porphyries from the La Sal Mountains, Utah, and the Carroizo Mountains, Arizona o...................... 38

12. Spectrographic analyses of metalliferous vein deposits from the Ia Sa.I Mountains, Utah ....... 39

13. Spectrographie analyses of copper sulfide sulfarsenide vein deposits in sandstone ........ 41

14. Spectrographic analyses of uranium-bearing vein deposits of unusual types ................ 43

15. Spectrographic ana.1yses of mi.1. -pulp samples of uranium ores

A. Cortez district, Grants district, House Rock district ......................... 44

B. Gateway district ...................... 45

C. Gypsum Va.11ey and Southern Bul1 Canyon

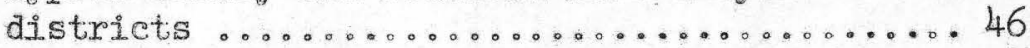

D. Henry Mountains district ............... 47

E. Moab distriet . ....................... 48

F. Monticello distriet $\ldots \ldots \ldots \ldots \ldots \ldots . \ldots . \ldots 49$

G。 Monument Valley district .............. 51 .

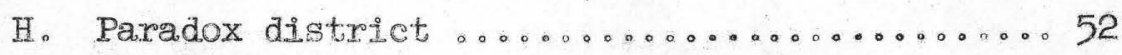

I. San Rafael and western Green River districts . 53

J. Shiprock district $\ldots \ldots \ldots \ldots \ldots \ldots \ldots \ldots \ldots \ldots \ldots$

K. Slick Rock distriet $\ldots \ldots \ldots \ldots \ldots \ldots \ldots \ldots 55$

I. Thompsons and eastern Green River districts .. 58 
CONFIDENTIAL

SECURITY INFORMATION

6

TABLES (cont.)

Pa.ge

M. Uravan and northern Bull Canyon districts .... 59

$N$. White Canyon district $\ldots \ldots \ldots \ldots \ldots \ldots \ldots$

0 . List of mill-pulp samples from mines in preMorrison formations ..............6 63 
DISTRIBUTION OF ORE DEPOSITS AND SPECTROGRAPHIC ANALYSES

OF SOME ROCKS AND ORES ON THE COLORADO PLATTEAU

By

Leonard B. Riley and Eugene M. Shoemaker

ABSTRACT

The geographic pattern of known igneous rocks and ore deposits on the Colorado Plateau suggests a zonal arrangement of several types of ore deposits around centers of igneous activity.

Spectrographic analyses of rocks and ores on the Plateau have been obtained in an effort to determine the distribution of elements and to examine the relationships between types of ore deposits and between the ore deposits and igneous rocks. Over 170 analyses of rocks and ores are given in this report. A preliminary study of these analyses suggests that the proportion of uranium, vanadium, copper, and silver in the uranium ores varies geographically, and that the pattern of variation may be in part concentric about some of the major laccolithic intrusions. It is also suggested that the following ratios of metals contained in the uranium ores are possible guides to largerthan-average ore deposits: (1) lead/uranium greater than 1, (2) lead/ zine greater than 10, and (3) zine/geometric mean of cobalt and nickel less than 10 . 
CONFIDENTIAL

SECURITY INFORMATION

8

\section{INTRODUCTION}

The geographic pattern of known igneous rocks and ore deposits on the Plateau suggests a broad zonal distribution of ore metals across the Plateau combined with a zonal. arrangement of several types of ore deposits around centers of igneous activity. The distribution of ore deposits and intrusive igneous rocks may be seen on "Map of the uranium region of the Colorado Plateau," compiled by E. M. Shoemaker and R.G. Luedke (TEI-279)。This map was originally planned to accompany this report. It has since been separated in order that it may be placed. on open fiile.

Spectrographic analyses of rocks and ores on the Colorado Plateau have been obtained in an effort to determine the distribution of elements in the different types of rocks and ore deposits. This study of the distribution of the elements was undertaken to determine the possible pattern of distribution of metals associated with the ore deposits and. to examine the relationships between the different types of ore deposits and between the ore deposits and the igneous rocks. Over 170 semiquantitative spectrographic analyses representing many different types of rocks and ores have been gathered, partly from the files of the Geological Survey, but chiefly from new ana.lyses made specifically for the purpose of this investigation. Although the investigation has only begun, this report has been written to make the results of the spectrographic analyses available to other research workers. This work was done on behalf of the Division of Raw Materials of the U. S. Atomic Energy Commission. 
GEOLOGIC SEIPING OF THE COLORADO PLATEAU

The rocks exposed on the Colorado Plateau are chiefly sedimentary beds of Paleozoic, Mesozolic, and Cenozoic age. These beds are in genera.l nearly flat lying, but the Colorado Plateau as a whole is gently warped into broad uplifts and basins. Steep-dipping faults of comparatively sma.1. displacement are common on the flanks of the upIifts and in a northwest-trending belt in the north-central part of the Plateau. Crystalline rocks of pre-Cambrian age are loca.11y expcsed at the centers of some uplifts. Igneous rocks of Cenozoic age are widely distributed on the Plateau; intrusive rocks form scattered. mountain ranges in its central part, and 1 t is nearly encompassed by extersive roleanic fields.

\section{Sedimentary rocks}

The sedimentary rocks of the Plateau comprise sandstone, mudstone, and limestone. More than half of these beds are continental deposita; nearly ha.lf of the beds are sandstone. The stratigraphic sequence from upper Paleozole to lower Tertiary is unusually complete. A generalized. section of Pennsylvanian to Eocene strata in the central and northern part of the Plateau is given in table 1.

\section{Igneous rocks}

The Cenozolic Igneous rocks of the Colorado Plateau comprise a distinetly a.1kaline suite, and most of the rocks of intermediate to silicic 
Table 1.--Generalized section of Pennsylvanian to Eocene strata. in the north-central part of the Colorado Plateau

$\begin{array}{llr}\text { System Group or formation } & \text { Thickness } & \text { Character and } \\ \text { (feet) } & \text { distribution }\end{array}$

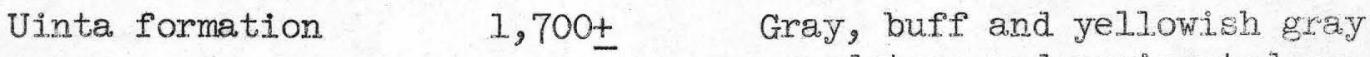
sandstone and variegated or gray shale; present in northern Utah and Colorado.

$\begin{array}{cc}\text { Eocene } & \begin{array}{c}\text { Green River } \\ \text { formation }\end{array}\end{array}$

Shale, oil shale, and marlstone, gray to grayish brown with interbedded browh sandstone; present in northern Utah and Colorado.

Wasatch group 3,000 or + Varicolored shale, sandstone, and Iimestone; widespread.

\begin{tabular}{|c|c|c|c|}
\hline \multirow{5}{*}{ Cretaceous } & \multirow[b]{2}{*}{ Mesa Verde group } & \multirow{2}{*}{$1,000+$} & \\
\hline & & & $\begin{array}{l}\text { Light-colored sandstone and } \\
\text { gray shale; coal-bearing; } \\
\text { cliff-forming; widespread. }\end{array}$ \\
\hline & Mancos shale & $2,000-5,000$ & $\begin{array}{l}\text { Gray shale; forms valleys and } \\
\text { steep slopes; widespread. }\end{array}$ \\
\hline & Dakota sandstone & $50-200$ & $\begin{array}{l}\text { Gray and brown sandstone and } \\
\text { sha.le; mesa-capping; wide- } \\
\text { spread. }\end{array}$ \\
\hline & $\begin{array}{l}\text { Burro Canyon } \\
\text { formation }\end{array}$ & $50-250$ & $\begin{array}{l}\text { Light-colored conglomeratic } \\
\text { sandstone and green and maroon } \\
\text { mudstone; mesa-capping. }\end{array}$ \\
\hline \multirow{4}{*}{ Jurassic } & \multirow[t]{2}{*}{ Morrison formation } & $300-500$ & $\begin{array}{l}\text { Brushy Basin shale member: } \\
\text { varicolored sha.le (or mud- } \\
\text { stone), some sandstone lenses; } \\
\text { forms slopes; widespread. }\end{array}$ \\
\hline & & $200-400$ & $\begin{array}{l}\text { Salt Wash sandstone member: } \\
\text { Light-colored sandstone and } \\
\text { red mudstone; forms cliffs and } \\
\text { benches; widespread. }\end{array}$ \\
\hline & $\begin{array}{l}\text { Summerville } \\
\text { formation }\end{array}$ & $50-400$ & $\begin{array}{l}\text { Red and gray shale, thin sand } \\
\text { stone; forms slopes; thickens } \\
\text { westward. }\end{array}$ \\
\hline & Curtis formation & $0-250$ & $\begin{array}{l}\text { Glauconitic sandstone, greenish } \\
\text { shale, gypsum; present in } \\
\text { centra.1 Utah only. }\end{array}$ \\
\hline
\end{tabular}

CONFIDENTIAL SECURITY INFORMATION 
Table 1..-Continued

$\begin{array}{lll}\text { System Group or formation } & \text { Thickness } & \text { Character and } \\ \text { (feet) } & \text { distribution }\end{array}$

Entrada sandstone $\quad 50-1,000$

Jurassic

Carmel formation $\quad 0-600$
Light-colored, massive, c.liffforming sandstone in Colorado and eastern Utah; thickens westward and becomes red, earthy sandstone.

Red, earthy sandstone in

Colorado and eastern Utah; thickens westward and becomes gray and red shale, limestone, and gypsum.

Navajo sandstone

$0-2,000$

Light-colored, massive sandstone; cliff-forming; generally absent in Colorado, thickens westward.

Jurassic(?) Kayenta formation

$0-300$

Red sandstone, irregularly bedded; bench-forming; absent in eastern part of region.

Wingate sandstone $\quad 0-400$

Red, massive sandstone; cliffforming, absent in eastern part of region.

Red shale and sandstone; forms slopes; widespread.

Light-colored conglomeratic sandstone and shale; benchforming; absent in Colorado. Red-brown shale and sandstone; forms slopes; absent in eastern part of region.

Red and gray sha.le, arkose, and conglomerate; thickest in Colorado (though absent in places), thins gradually westward.

Hermosa formation $\quad 0-5,000$

Pennsylvanian
Limestone, shale, gypsum, salt and arkose; exposed across uplifts and in salt intrusions, thins southwestward. 
composition axe soda rich (table 2). The intrusive rocks of the central. part of the Plateau form two groups, laccoliths and stocks ranging in composition from diorite to syenite, and dikes and plugs of lamprophyric composition. Most of the laccoliths are diorite of nearly the same composition throughout the central part of the Plateau (table 2). Volcanie rocks on the periphery of the Plateau range in composition from olivine basalt to rhyolite. Most yolcanic rocks of intermediate composition are similar chemically to the laccolithic rocks. It seems evident that the Colorado Plateau is a single province of closely related rock types.

TYPES OF ORE DEPOSITS ON THE COLORADO PLATEEAU

Metal deposits are widely distributed on the Colorado Plateau and occur in nearly all of the sedimentary formations, in the Cenozoic igneous rocks, and also in the pre-Cambrian crystalline rocks. Most of the deposits are small and only the uranium-bearing deposits in the sedimentary formations have been of major economic importance. The deposits can be broadly clsssed into two types, vein deposits and bedded deposits.

\section{Vein deposits}

Vein deposits occur both in and near intrusive igneous rocks and also far from amy known igneous intrusions in sedimentary rocks. Vein deposits in the igneous rocks are restricted to stocks and laccoliths. These deposits include: (1) gold-pyrite-chalcopyrite-bornite veins and replace- 
Table 2.--Chemical analyses of laccolithic and other intrusive rocks on the Colorado Plateau

$\begin{array}{llllllll}1 & 2 & \underline{3} & \underline{4} & \underline{6} & \underline{6} & 1 & \underline{8}\end{array}$

\begin{tabular}{|c|c|c|c|c|c|c|c|c|}
\hline $\begin{array}{l}\mathrm{SiO}_{2} \\
\mathrm{Al}_{2} \mathrm{O}_{3}\end{array}$ & $\begin{array}{l}62.58 \\
17.61\end{array}$ & $\begin{array}{l}61.21 \\
17.10\end{array}$ & $\begin{array}{l}63.18 \\
16.47\end{array}$ & $\begin{array}{l}62.65 \\
16.68\end{array}$ & $\begin{array}{l}62.85 \\
16.21\end{array}$ & $\begin{array}{l}68.96 \\
15.42\end{array}$ & $\begin{array}{l}58.99 \\
10.01\end{array}$ & $\begin{array}{l}50.01 \\
17.98\end{array}$ \\
\hline $\begin{array}{l}\mathrm{Fe}_{2} \mathrm{O}_{3} \\
\mathrm{FeO}\end{array}$ & $\begin{array}{l}2.36 \\
2.40\end{array}$ & $\begin{array}{l}2.72 \\
1.88\end{array}$ & $\begin{array}{l}2.36 \\
2.28\end{array}$ & $\begin{array}{l}2.35 \\
2.63\end{array}$ & $\begin{array}{l}3.08 \\
1.46\end{array}$ & $\begin{array}{r}1.99 \\
.16\end{array}$ & $\begin{array}{r}1.74 \\
.59\end{array}$ & $\begin{array}{l}3.05 \\
3.26\end{array}$ \\
\hline $\begin{array}{l}\mathrm{MgO} \\
\mathrm{CaO}\end{array}$ & $\begin{array}{l}1.43 \\
5.31\end{array}$ & $\begin{array}{l}1.47 \\
4.83\end{array}$ & $\begin{array}{l}1.33 \\
4.77\end{array}$ & $\begin{array}{l}1.43 \\
4.96\end{array}$ & $\begin{array}{l}1.47 \\
4.27\end{array}$ & $\begin{array}{l}.22 \\
.25\end{array}$ & $\begin{array}{r}.27 \\
2.02\end{array}$ & $\begin{array}{l}3.13 \\
7.09\end{array}$ \\
\hline $\begin{array}{l}\mathrm{Na}_{2} \mathrm{O} \\
\mathrm{K}_{2} \mathrm{O}\end{array}$ & $\begin{array}{l}5.05 \\
1.85\end{array}$ & $\begin{array}{l}5.66 \\
3.00\end{array}$ & $\begin{array}{l}4.40 \\
2.93\end{array}$ & $\begin{array}{l}4.45 \\
2.75\end{array}$ & $\begin{array}{l}3.49 \\
3.10\end{array}$ & $\begin{array}{l}6.59 \\
5.48\end{array}$ & $\begin{array}{l}9.11 \\
5.07\end{array}$ & $\begin{array}{l}4.43 \\
4.82\end{array}$ \\
\hline $\begin{array}{l}\mathrm{H}_{2} \mathrm{O} \\
\mathrm{H}_{2} \mathrm{O} \\
\mathrm{TiO}_{2} \\
\mathrm{ZrO}_{2} \\
\mathrm{CO}_{2} \\
\mathrm{P}_{2} \mathrm{O}_{5} \\
\mathrm{SO}_{3} \\
\mathrm{Cl} \\
\mathrm{MnO} \\
\mathrm{BaO} \\
\mathrm{SrO} \\
\mathrm{Li} 2 \mathrm{O}\end{array}$ & $\begin{array}{c}\{.74 \\
.42 \\
-\infty \\
\cdots \\
\therefore \\
\therefore \\
\therefore \\
.26 \\
- \\
- \\
99.82\end{array}$ & $\begin{array}{r}.34 \\
.68 \\
.51 \\
.02 \\
-- \\
.24 \\
-- \\
.04 \\
.15 \\
.13 \\
.07 \\
\mathrm{Tr} \\
100.05\end{array}$ & $\begin{array}{c}.27 \\
.60 \\
.66 \\
-- \\
-- \\
.28 \\
-- \\
- \\
.15 \\
.15 \\
.09 \\
\text { Tr } \\
99.86\end{array}$ & $\begin{array}{c}.27 \\
.66 \\
.42 \\
.- \\
-. \\
.28 \\
- \\
- \\
.16 \\
.13 \\
.11 \\
\operatorname{Tr} \\
99.95\end{array}$ & $\begin{array}{c}2.32 \\
.41 \\
\cdots \\
-48 \\
-4 \\
- \\
.15 \\
.11 \\
-- \\
99.85\end{array}$ & $\begin{array}{c}.22 \\
.30 \\
.12 \\
.04 \\
.13 \\
\operatorname{Tr} \\
-- \\
.01 \\
.07 \\
\operatorname{Tr} \\
-- \\
\operatorname{Tr} \\
99.96\end{array}$ & $\begin{array}{r}.38 \\
1.24 \\
.21 \\
.07 \\
-\infty \\
.04 \\
.96 \\
.15 \\
.08 \\
.02 \\
.02 \\
T r \\
99.97\end{array}$ & $\begin{array}{c}0.27 \\
0.29 \\
2.00 \\
-- \\
.09 \\
.67 \\
.12 \\
-- \\
.10 \\
-- \\
-- \\
-- \\
99.97\end{array}$ \\
\hline
\end{tabular}

1. Diorite porphyry from South Creek laccolith, Henry Mountains, Utah.

2 Monzonite porphyry from middle mountain, LaSal Mountains, Utah.

3 Hornblende diorite porphyry, Carrizo Mountains, Arizona.

4 Hornblende diorite porphyry from Hermano Peak, Sleeping Ute Mountains, Colo.

5 Porphyritic diorite from Mount Marcellina, West Elk Mountains, Colorado.

6 Syenite porphyry from north mountain, LaSal Mountains, Utah.

7 Noselite syenite porphyry from north mountain, LaSal Mountains, Utah.

8 Analcite syenite from composite sill, San Rafael Swell, Utah.

All analyses by U. S. Geological Survey, 1894 - 1940.

CONFIDENTIAI, 
ment bodies, which occur in many of the laccolithic mountain groups of the Plateau, (2) gold-silver telluride veins, which occur in the La Plata Mountains of Colorado, and (3) ruby silver-gray copper veins, which occur in the West Elk Mountains of Colorado. Vein deposits in sedimentary rocks that are not demonstrably associated with igneous intrusions are of two types: (1) copper sulfide and sulfarsenide veins, which occur chiefly in an arcuate belt around the La Sal Mountains, and (2) veins that contain both copper and uranium minerals associated with a wide variety of other meta.ls. These copper-uranium-bearing veins are rare but are found at widely separated localities on the Plateau.

\section{Bedded deposits}

Bedded deposits can be classified most conveniently according to their metal content. Divided on this basis the bedded deposits comprise four main types: (1) uranium-vanadium deposits, (2) copper-uranium deposits, which are nearly a.lways accompanied by detectable amounts of vanadium and silver, (3) copper deposits, the so-called "red beds" type, and (4) manganese deposits. Many gradational types between the first three classes of deposits can be cited. The ore minerals in these deposits are disseminated in the sedimentary rocks and commonly appear to be influenced in their distribution by certain sedimentary structures of these rocks. Only rarely do regional structures obviously affect the distribution of the ore minerals in the sedimentary host. The 
distribution of bedded deposits in the stratigraphic column is shown by examples in table 3. This tabulation is not necessarily complete. The principal production of uranium has come from three formations: the Shinarump conglomerate of Upper Triassic age, the Entrada sandstone of Upper Jurassic age, and the Morrison formation also of Upper Jurassic age.

\section{SPECTROGRAPHIC ANALYSES}

\section{Sensitivity of the spectrographic method}

Spectrographic analyses have been used in this investigation because they are rapid and inexpensive, and because in many cases they are sensitive in the range of concentration below that which can be estimated by ordinary chemical means. The concentration of the elements that can be estimated by the spectrographic method, at their threshold of detection, is shown in table 4. The threshold values shown in table 4 are those attained in the laboratories of the Geological Survey with particular reference to materials from the Colorado Plateau.

All of the spectrographic analyses reported here have been made by the Geochemistry and Petrology Branch, Trace Elements Section Washington and Denver laboratories. The samples analyzed in the Washington laboratory carry the suffix $W$ after the sample number, and those analyzed in Denver carry the suffix D after the sample number, as reported in the following tables 8 to 15 . Chemical assays included in table 15 were calculated from the records of American Smelting and Refining Company. 
Examples of deposits

\begin{tabular}{|c|c|c|c|c|}
\hline Formation or group & Uranium-vanadium & Copper & Copper -uranium & Manganese \\
\hline $\begin{array}{l}\text { Uinta formation } \\
\text { Green River formation } \\
\text { Wasatch group }\end{array}$ & & & Myton, Utah & \\
\hline Mesa Verde group & La Ventana, N. Mex. & & & \\
\hline Mancos shale & Saleratus Wash, Utah & & & \\
\hline $\begin{array}{l}\text { Dakota sandstone and } \\
\text { Burro Canyon-Cedar } \\
\text { Mountain formation }\end{array}$ & $\begin{array}{l}\text { Rifle Creek, Colo. } \\
\text { Bullock Claim, } \\
\text { Utah }\end{array}$ & $\begin{array}{l}\text { Tabeguache Basin, } \\
\text { Colo. }\end{array}$ & & \\
\hline Morrison formation & Club mine, Colo. & $\begin{array}{l}\text { Pioneer mine, } \\
\text { Utah }\end{array}$ & Cougar mine, Colo. & \\
\hline Summerville formation & $\begin{array}{l}\text { Little Gypsum Valley, } \\
\text { Colo. }\end{array}$ & & & $\begin{array}{l}\text { Little Grand } \\
\text { dist., Utah }\end{array}$ \\
\hline $\begin{array}{l}\text { Curtis-Pony Express- } \\
\text { Todilto limestone }\end{array}$ & Grants, N. Mex。 & & $\begin{array}{l}\text { Skull Creek, } \\
\text { Colo. }\end{array}$ & \\
\hline $\begin{array}{l}\text { Entrada sandstone } \\
\text { Carmel formation }\end{array}$ & Placerville, Colo. & & Brush Creek, Colo. & \\
\hline $\begin{array}{l}\text { Navajo sandstone } \\
\text { Kayenta formation }\end{array}$ & $\begin{array}{l}\text { Riflle mine, Colo. } \\
\text { Roc Creek, Colo. }\end{array}$ & $\begin{array}{l}\text { White Mesa, Ariz. } \\
\text { Sinbad Valley, } \\
\text { Colo. }\end{array}$ & Richardson, Utah & \\
\hline Wingate sandstone & $\begin{array}{l}\text { Temple Mountain, } \\
\text { Utah }\end{array}$ & & & \\
\hline Chinle formation & & Cuba, N. Mex. & Silver Reef, Utah & \\
\hline $\begin{array}{l}\text { Shinarump } \\
\text { conglomerate }\end{array}$ & $\begin{array}{l}\text { Monument No. } 2 \text {, } \\
\text { Ariz. }\end{array}$ & & Fosey linne, U tan & \\
\hline Moenkopi formation & & $\begin{array}{l}\text { Capitol Reef, } \\
\text { Utah }\end{array}$ & & \\
\hline $\begin{array}{l}\text { Permian formations } \\
\text { Hermosa formation }\end{array}$ & $\begin{array}{l}\text { Big Buck mine, Utah } \\
\text { Bald Eagle mine, } \\
\text { Colo. }\end{array}$ & Zuni Mts., No. Mex. & $\begin{array}{l}\text { Hacks Canyon, Ariz. } \\
\text { Sinbad Copper mine, } \\
\text { Colo. }\end{array}$ & \\
\hline
\end{tabular}


Table 4.--Threshold values of elements included in the semiquantitative spectrographic method, with particular reference to materials analyzed from the Colorado Plateau I/

\section{Element}

A.luminum Antimony Arsenic

Ba,roium Beryl1.ium Bismuth

Boron.

Cadmium

Ca.lcium

Cerium

Chromium

Coba.It

Copper.

Ca.11ium

Gold

Iron

Lanthanum

Lead.

Magnesium

Manganese

Molybdenum

Nickel.

Phosphorous

Potassium

Seandium

Silicon

Silver

Sodium

Strontium

Thorium

Tin.

Titanium

Uranium

Vanadium

Ytterbium

Yttroium

Zine

Zirconium
Group no.

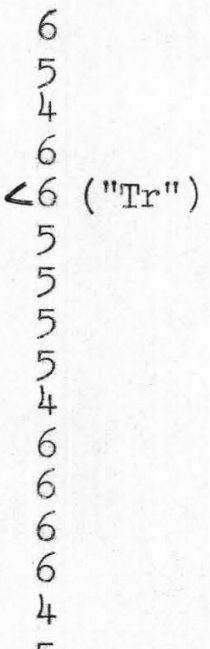

5

5

$<6$ ("Tr")

6

6

6

3

.3

6

6

$<6(" T r e)$

4

6

3

5

5

3

5

6

6

4

6
Percent

0.0001

.001

.01

.0001

$<.0001$

.001

.001

.001

.001

.01

.0001

.0001

.0001

.0001

.01

.001

.001

$<.0001$

.0001

.0001

.0001

.0001

. 1

.1

.0001

.0001.

$<.0001$

.01

.0001

. 1

.001

.001

.1

.001

.0001

.0001.

.01

.0001
Parts per million

1
10
100
1
$<1$
10
10
10
10
100
1
1
1
1
100
10
10
41
1
1
1
1
1000
1000
1
1
100
1000
10
10
1000
10
1
100
1

I/ A longer list of elements (69) with threshold values applying to material in general may be found in TEI-182, page 26. Most of the elements given there, but omitted here, have been looked for, but not found, in the analyses of the Colorado Plateau materials.

Among the elements not detectable by this method are carbon, selenium, and sulfur。 
Group number method of reporting spectrographic analyses

The "group-number" method of reporting results of spectrographic analyses of Colorado Plateau materials for this investigation is shown by the following data:

Group no.

1

2

3

4

$\frac{5}{6}$

Percent
10 to 100
1 to 10
0.1 to 1
0.01 to 0.1
0.001 to 0.01
0.0001 to 0.001

Parts per million 100,000 to $1,000,000$ 10,000 to 100,000 1,000 to 10,000 100 to 1,000 10 to $\quad 100$ 1 to 10

In the tabulations of the elements in various samples, plus and minus signs after group numbers show the relative position within the group: plus--toward the upper limit of the range indicated, and minus--toward the lower limit. A zero (0) has been used to signify that the element has been looked for but not found and that it is presumably below the limit of detection (threshold value). An asterisk (*) has been used where the element was not looked for, or the results are not available, or where the normal threshold value could not be reached because of interference.

\section{Average composition of rocks and ores}

The calculated average chemical compositions of the sandstone and the mudstone and shale of the Salt Wash sandstone member of the Morrison formation are shown in tables 5 and 6 . Although the precision is low, because of the relatively small number of samples, the results compare well with the compositions of average sandstone and average shale given by other 
authors, whereas the chemical compositions of nearly half of the elements studied contrast strongly with the average composition of the 99 millpulp samples of bedded uranium deposits shown in table 7 .

The average used here is the geometric mean. This mean is not only moderately easy to compute from the data as presented, but is the more appropriate average because most of the chemical elements trend toward. as ymmetrie distributions.

The Salt Wash rocks are surprisingly "average" in their compositions. The mudstoxer is significantly low only in titanium, chromium, and copper. The sandstone is a.lso low in chromium, less so in titanium. The apparent deficiency of lead in the sandstone may be due to the fact that its amount was estimated from the heavy mineral fraction of a few sandstones, and part of the lead of the sandstone may well be contained in one of its lighter minerals, such as feldspar.

The number of heavy (sp. gr. more than 2.9) mineral fractions analyzed is only five, but these indicate that most of the zirconium, iron, titanium, chromium, and copper of the unmineralized sandstone is contained in its detrital minerals. In addition most of the strontium, part of the barium, and about $1 / 10$ of the total vanadium of the unmineralized sandstone is found in the heavy mineral fraction. Silver, the one metal that could be the result of significant contamination from acetylene tetrabromide used in heavy mineral separation is so closely proportional to the other elemerts contained in the detrital minerals as to suggest that is has a similar occurrence. There is a.lso some suggestion that boron, nickel, and 
cobalt are also contained in the detrital minerals of the unmineralized sandstone.

The composition of the sandstones and mudstones serves as a background for studying the composition of the ores. The average composition of the ores of the bedded uranium deposits (table 7) when compared to the average Salt Wash sandstone, shows additions of copper, cobalt, and lead and probably of nickel and strontium, as well as uranium and vanadium. Comparison of the amounts of arsenic, zine, scandium, gallium, and beryllium suggests possible increases in the average ores, but more information is needed to confirm this suggestion. There is little evidence of a significant decrease of any element from the sandstones to the ores. The proportion of calcium ( 3 percent in the sandstone, 0.7 percent in the ore), the apparent exception, is probably influenced by mill penalties imposed on high-lime ores.

Study of individual deposits corroborates the inferred increase of many metals in the ore deposits as deduced from the comparison of average ores and barren sandstone and shale. Specifically, nickel, zinc, and silver are known to have a broad range of concentration in the ores even though the average composition of the ores shows only moderate increase in these metals over the barren rocks. (See "Variation of metal content in bedded uranium ores.")

Variation of metal content in bedded uranium ores

The variation of metal content in the bedded uranium ores was studied by means of production data and by analyses of composite samples built 
Table 5.--Average chemical composition of Salt Wash mudstones and shales compared with the average composition of shales

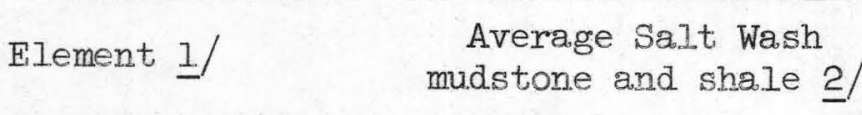

Average shale $3 /$

\begin{tabular}{|c|c|}
\hline Si. & $>10 \%$ \\
\hline A.1 & $>10 \% 4 /$ \\
\hline K & $3 \%-$ \\
\hline Na & $0.8 \%$ \\
\hline $\mathrm{Fe}$ & $4 \% 5$ \\
\hline $\mathrm{Mn}$ & $0.02 \%$ \\
\hline $\mathrm{Ca}$ & $4 \% 5$ \\
\hline $\mathrm{Mg}$ & $1 \%$ \\
\hline $\mathrm{Ba}$ & $0.02 \% 6$ \\
\hline $\mathrm{Sr}$ & $0.02 \%$ \\
\hline Ti & $0.04 \%$ \\
\hline $\mathrm{Zr}$ & $0.01 \%$ \\
\hline $\mathrm{Cr}$ & $30 \mathrm{ppm}$ \\
\hline $\mathrm{Ga}$ & $30 \mathrm{ppm}$ \\
\hline $\mathrm{Sc}$ & $<100 \mathrm{ppm} 8$ \\
\hline $\mathrm{Y}$ & $\therefore .10$ ppm 8 \\
\hline Ia & $<100 \mathrm{ppm} \overline{8}$ \\
\hline $\mathrm{Be}$ & < $\quad 1$ ppm 8 \\
\hline$B$ & $<10 \mathrm{ppm} 8$ \\
\hline$U$ & $<0.1 \% 8$ \\
\hline $\mathrm{V}$ & $70 \mathrm{ppm}$ \\
\hline$N i$ & 20 ppm 9/ \\
\hline Co & $<40 \mathrm{ppm} 8$ \\
\hline $\mathrm{Cu}$ & 20 ppm 9 \\
\hline $\mathrm{Pb}$ & $<10 \mathrm{ppm} 8$ \\
\hline $\mathrm{Zn}$ & $<0.01 \% 87^{\prime}$ \\
\hline $\mathrm{Cd}$ & $<10 \mathrm{ppm}^{-8}$ \\
\hline Mo & $<\quad 1$ ppm 8 \\
\hline As & $<0.1 \% 8$ \\
\hline$\Delta 0$ & $<\quad 10 \mathrm{ppm} 8$ \\
\hline
\end{tabular}

$$
\begin{aligned}
& 27.3 \% \\
& 8.1 \% \\
& 2.7 \% \\
& 0.97 \% \\
& 4.7 \% \\
& 0.06 \% \\
& 2.2 \% \\
& 1.5 \% \\
& 0.06 \% \\
& 0.017 \% \\
& 0.43 \% \\
& 0.012 \% \\
& 410-680 \mathrm{ppm} \\
& 50 \mathrm{ppm} \\
& 6.5 \mathrm{ppm} \\
& 28 \mathrm{ppm} \\
& \text { not given } \\
& 3.6 \mathrm{ppm} \\
& 310 \mathrm{ppm} \\
& 1.2 \mathrm{ppm} \\
& 120 \mathrm{ppm} \\
& 24 \mathrm{ppm} \\
& 8 \mathrm{ppm} \\
& 192 \mathrm{ppm} \\
& 20 \mathrm{ppm} \\
& 0.02-0.10 \% \\
& 0.3 \mathrm{ppm} \\
& \text { not given } \\
& \text { a.bout } 5 \mathrm{ppm} \\
& 0.05 \mathrm{ppm} \\
&
\end{aligned}
$$

1) The composition is given by elements, not by conventional oxides.

2) From eleven samples collected for stratigraphic clay studies by A. D. Weeks (table 10).

3) Rankama, Kalervo, and Sahama, Th. G., Geochemistry, Chicago, 1950, table 5.52, page 226.

4) Aluminum is slightly less than silicon.

5/ Iron is slightly greater than calcium.

6) Barium is slightly less than strontium.

7) Gallium is slightly greater than chromium.

8) Below the threshold value of the spectrographic analysis for this material; threshold values for analyses shown in table 10 are not necessarily the threshold values shown in table 4 .

9/ Nickel is slightly greater than copper. 
Table 6.--Average chemical composition of Salt Wash sandstones compared with the average composition of sandstones

Si

A.]

K

$\mathrm{Na}$

$\mathrm{Fe}$

$\mathrm{Mn}$

$\mathrm{Ca}$

$\mathrm{Mg}$

Ba

Sr.

Ti.

Zr

Cro

Ga.

$\mathrm{Sc}$

$\Psi$

La 5

$\mathrm{Be}$

B

$\mathrm{U}$

$\mathrm{V}$

Ni $\frac{5}{5 /}$

$\mathrm{Cu}$

$\mathrm{Pb} 5 /$

$\mathrm{Zn}$

cd.

MO

As

A.g

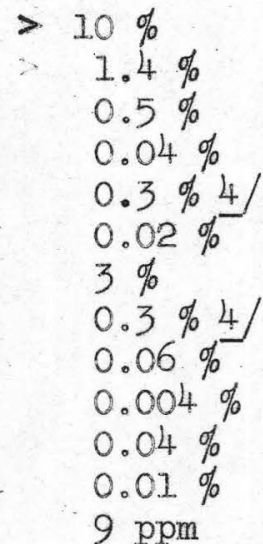

$0.01-0.1 \mathrm{ppm}$

$0.01-0.1 \mathrm{ppm}$

1-10 ppm

$0.1-1 \mathrm{ppm}$

$0.001-0.0 .1 \mathrm{ppm}$

1-10 ppm

$<0.1 \% 6 /$

$30 \mathrm{ppm}$

$0.1-1 \mathrm{ppm}$

$0.01-0.1 \mathrm{ppm}$

$8 \mathrm{ppm}$

0.01-0.1 ppm

< 100 ppm 6/

< 10 ppm 6

<. $1 \mathrm{ppm} 6 /$

$<1.00$ ppm 6/

$0.2-2 \mathrm{ppm}$
$36.75 \%$

$2.53 \%$

$1.1 \%$

$0.33 \%$

$0.99 \%$

Trace

$3.95 \%$

$0.71 \%$

$0.017 \%$

$<0.0026 \%$

$0.096 \%$

not given

68-220 ppm

$7.4 \mathrm{ppm}$

$0.7 \mathrm{ppm}$

$1.6 \mathrm{ppm}$

not given

not given

9-31 ppm

$1.2 \mathrm{ppm}$

$20 \mathrm{ppm}$

$2-8 \mathrm{ppm}$

0

not given

$20 \mathrm{ppm}$

20. $\mathrm{ppm}$

0

not given

not given

$0.44 \mathrm{ppm}$

1/ The composition is given by elements, not by conventional oxides.

2) Average of the 25 analyses shown in table 8 .

3) Rankama, Kalervo, and Sahama, Th. G., Geochemistry, Chicago, 1950, table 5.52, page 226.

4. Magnesium is slightly greater than iron.

5) Concentrations estimated from the concentration of elements found in five heavy mineral fractions (table 9). A ratio of concentration of about 150 to 1 was used.

6/ Below the threshold value of the spectrographic analysis for this material (table 4). 
Table 7.- Average chemical composition of bedded uranium ore deposits from spectrographic analyses of 99 mill-pulp samples

\section{Element I/}

Si.

Al

$\mathrm{K}$

Na

$\mathrm{Fe}$

Mn

Ca.

$\mathrm{Mg}$

$\mathrm{Ba}$

Sr.

Tis

$\mathrm{Zr}$

Cro

Ga

Se

$\mathrm{Y}$

La

$\mathrm{Be}$

B

U

V.

Ni.

Co

$\mathrm{Cu}$

$\mathrm{Pb}$

$\mathrm{Zn}$

$\mathrm{Cd}$

Mo

As

$\mathrm{Ag}$
Average composition

$$
\begin{aligned}
& >10 \% \\
& 3 \% \\
& 0.2-2 \% 2 / \\
& 0.07-0.1 \% \underline{2} \\
& \text { 2. \% } \\
& 0.03 \% \\
& 0.7 \% \\
& 0.3 \% \\
& 0.1 \% \\
& 0.02 \% \\
& 0.07 \% \\
& 0.01 \% \\
& 20 \mathrm{ppm} \\
& 3-6 \mathrm{ppm} 2 / \\
& 4-10 \mathrm{ppm} 2 / \\
& 10-20 \mathrm{ppm} / \\
& <10 \text { ppm 3/ } \\
& 0.8-3 \mathrm{ppm} 2 / \\
& 8 \text { - } 20 \text { ppm } 2 \\
& 0.3 \% 4 \\
& 0.5 \% \\
& 20 \mathrm{ppm} \\
& 20 \mathrm{ppm} \\
& 100 \mathrm{ppm} \\
& 200 \mathrm{ppm} \\
& \begin{array}{r}
100-300 \mathrm{ppm} \\
?-100 \mathrm{ppm} / \\
5 /
\end{array} \\
& 30 \mathrm{ppm} \\
& <100 \text { ppm 3/ } \\
& 0.4-4 \mathrm{ppm} 26
\end{aligned}
$$

1/ The composition is given by elements, not by conventional oxides.

2/ The lower figure is the result of extrapolation of that part of the assays below threshold value.

3) Below threshold value of the spectrographic analysis for this material. (see table 4).

4. The chemical assays in table 15, weighted to tons (9,896 total tons) give an average of 0.228 percent $\mathrm{U}_{3} \mathrm{O}_{8}$ (weighted arithmetic mean).

5/ Due to interference by vanadium, only 22 assays were available for the cadmium average. 


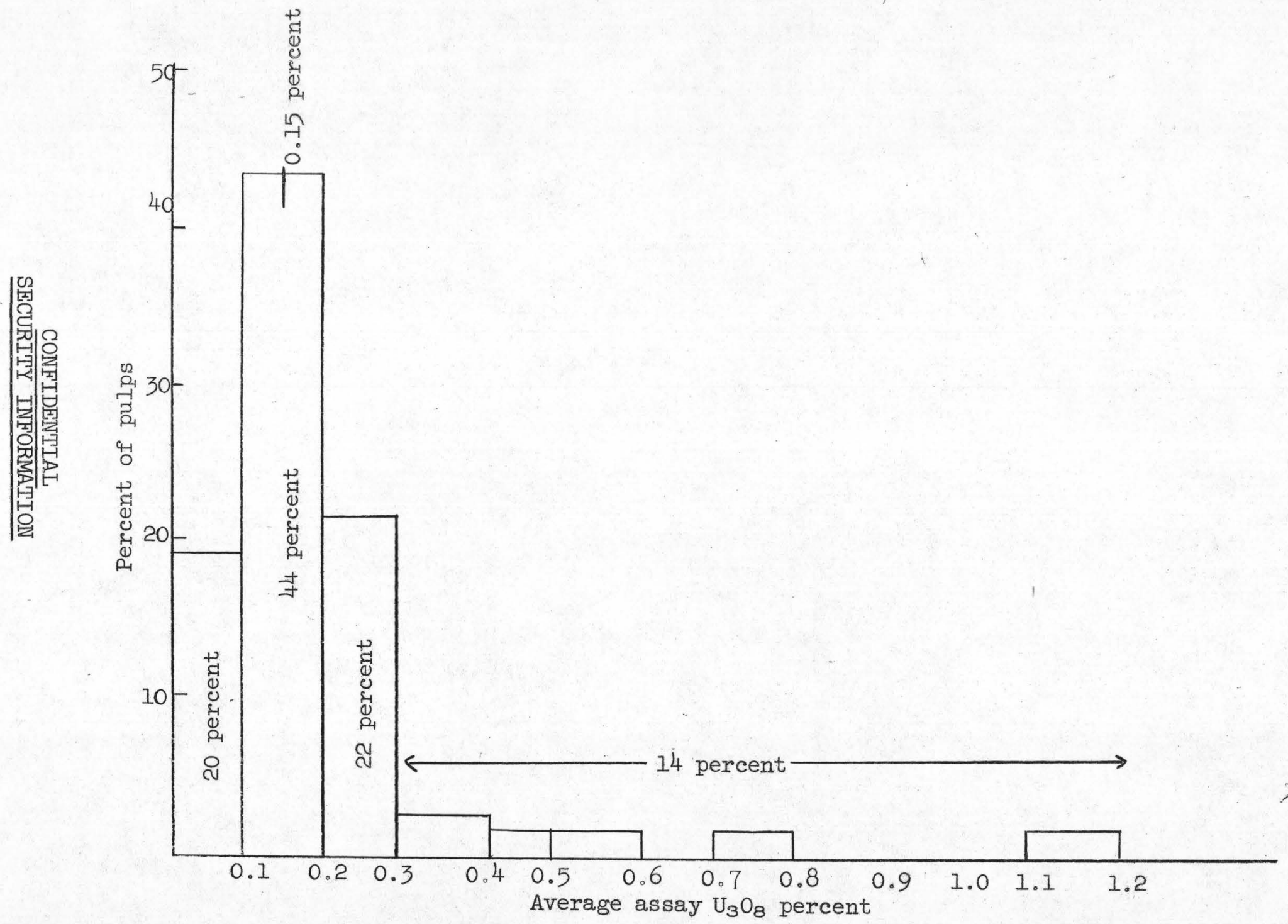

Figure 1.--Distribution histogram of average uranium assays of 59 mill-pulp samples 
from pulp samples of ore shipments to the mills. Composite samples, the analyses of which are reported in the following tables represent from a few tons to several hundred tons of ore from each mine. The average tonnage represented is about 1.00 tons per mine.

$$
\text { Ratio of } \mathrm{V}_{2} \mathrm{O}_{5} / \mathrm{U}_{3} \mathrm{O}_{3}
$$

The ratio of $\mathrm{V}_{2} \mathrm{O}_{5} / \mathrm{U}_{3} \mathrm{O}_{8}$ in the bedded uranium deposits has been studIed. from production data. Only mines which had a recorded production of 500 tons or more were studied in the investigation of this ratio. The preliminary results of this study are as follows:

(1) The $\mathrm{V}_{2} \mathrm{O}_{5} / \mathrm{U}_{3} \mathrm{O}_{8}$ ratio of bedded uranium deposits on the Colorado Plateau ranges from about 0.03 to about 30 , or varies by a factor of about 1000. The $\mathrm{V}_{2} \mathrm{O}_{5} / \mathrm{U}_{3} \mathrm{O}_{8}$ ratio in a small area within a district generally varies by not more than a factor of 3 .

(2) Within a small area variations in the $\mathrm{V}_{2} \mathrm{O}_{5} / \mathrm{U}_{3} \mathrm{O}_{8}$ ratio are greatest between deposits in different horizons in the same formation and between deposits in different formations. These variations, however, are generally not much greater than the variation between deposits in approximately the same horizon within the distriet. Thus, for example, where deposits in the Shinarump (or Cutler or Hermosa) formations are found in the same areas as deposits in the Morrison formation, the $\mathrm{V}_{2} \mathrm{O}_{5} / \mathrm{U}_{3} \mathrm{O}_{8}$ ratios of the deposits in the two different formations do not generally diverge by more than a factor of 5 .

(3) Deposits with $\mathrm{V}_{2} \mathrm{O}_{5} / \mathrm{U}_{3} \mathrm{O}_{8}$ ratios diverging by more than a factor of 20 are generally widely separated geographically. Geographic position, 
therefore, appears to be dominant over stratigraphic position in determining the $\mathrm{V}_{2} \mathrm{O}_{5} / \mathrm{U}_{3} \mathrm{O}_{8}$ ratio of the uranium deposits. The degree to which the pattern of $\mathrm{V}_{2} \mathrm{O}_{5} / \mathrm{U}_{3} \mathrm{O}_{8}$ ratios, however, is governed by stratigraphic position is not yet fully determined.

Variation of the $\mathrm{V}_{2} \mathrm{O}_{5} / \mathrm{U}_{3} \mathrm{O}_{8}$ ratio over the whole Plateau appears to be systematic, at least in a groșs way. The $\mathrm{V}_{2} \mathrm{O}_{5} / \mathrm{U}_{3} \mathrm{O}_{8}$ ratio ranges from high (20 to 30$)$ on the east side of the Plateau to low $(0.03$ to 0.05$)$ in the center as at White Canyon, and probably moderately low (less than 1) on the south and west sides. Several areas of high $\mathrm{V}_{2} \mathrm{O}_{5} / \mathrm{U}_{3} \mathrm{O}_{8}$ ratios ( 7 to 20) are superimposed on this regional gradient. It is believed that the areas of relatively high ratio are roughly centered around laccolithic mountains.

Elements largely contained in detrital minerals: titanium, chromium, zirconium, boron

The distribution of titanium, cbromium, zirconium, and boron indicated by the spectrographic analyses is as follows:

(1) Concentration of these elements generally does not vary by more than s factor of 100 .

(2) No significant difference is apparent, from the samples analyzed, in the titanium, chromium, zirconium, or boron content of the ores from the Morrison formation as contrasted with those from the Shinarump conglomerate.

(3) Areal patterns over the Plateau of the concentration in the ores of titanium, chromium, zirconium, and boron consist in general of scattered 


\title{
27
}

"low" and "high" spots. These patterns show no consistent relation with one another.

\author{
Metals of uncertain affinities: beryllium, \\ arsenic, molybdenum
}

The relation of beryllium, arsenic, and molybdenum to other metals in the ores is not known. Their distribution as indicated by the spectrographic analyses is as follows:

(1.) Concentration of arsenic and molybdenum varies by a factor of about 1000. The range of variation of beryllium is not known.

(2) Beryllium, arsenic, and molybdenum do not obviously favor either the Shinarump conglomerate or the Morrison formation. (Arsenic may be slightly more abundant in Shinarump ores.) On the whole the variation in amounts of beryllium, arsenic, and molybdenum appear to be regional rather than stratigraphic.

(3) The geographic patterns of the concentration of beryllium, arsenic, and molybdenum in the ores are different for each metal. Beryllium seems to be high on the south and west and low towards the northeast with an isolated high in the Slick Rock district. Arsenic seems to be high in a north-trending belt through the central part of the Plateau and low to the east and west. Molybdenum seems to be high in an arcuate belt through the central part of the Plateau and in scattered isolated areas. These three patterns do not correspond with one another or with any other known geologic features. 
Metals showing correlation with uranium ore: copper, silver, cobalt, nickel, lead, zinc

Copper, silver, cobalt, nickel, lead, and zinc all show correlation with other features of the uranium ores. Their distribution, indicated by the spectrographic analyses, is as follows:

(1) Concentrations of these elements vary by a factor of about 1000 .

(2) No preference of silver, cobalt, nickel, lead, or zinc for either the Morrison formation or the Shinarump conglomerate is apparent. Copper is widely distributed, ranging from 0.01 percent to 0.1 percent, in both the Morrison formation and the Shinarump conglomerate, but 1 percent to 1.0 percent of copper was found only in the Shinarump ores of White Canyon.

(3) The geographic patterns of the concentration of copper, silver, cobalt, nickel, lead, and zinc seem to be related. Copper in bedded deposits seems to have an inverse relation to the ratio $\mathrm{V}_{2} \mathrm{O}_{5} / \mathrm{U}_{3} \mathrm{O}_{8}$. Copper is higher where $\mathrm{V}_{2} \mathrm{O}_{5} / \mathrm{U}_{3} \mathrm{O}_{8}$ ratio is lower. The ratio of copper to silver is inverse to $\mathrm{V}_{2} \mathrm{O}_{5} / \mathrm{U}_{3} \mathrm{O}_{8}$ ratio. The copper to silver ratio is high in the central part of the Plateau (in the White Canyon district) and in the Uravan mineral belt area. It seems to be low over the laccolithic mountain areas. Cobalt and nickel vary directly with each other with few exceptions. Cobalt and nickel highs occur in the mineral belt area, in eastern Monument Valley, at the Happy Jack mine, and Temple Mountain. Interpretation of the distribution of lead is complicated by the presence of lead of at least two different origins. Both radiogenic and common lead are probably present in nearly all bedded uranium deposits on the Plateau. If the 
deposits are of the same order of magnitude in age, then the addition of radiogenic lead to the deposits since they were formed has probably tended to decrease the variation in $\mathrm{Pb} / \mathrm{U}$ ratios from the original range of variation. In spite of this, the present pattexn of lead distribution probably reflects at least in part the distribution of common lead. This $\mathrm{Pb} / \mathrm{U}$ pattern corresponds fairly closely with the patterns of cobalt and nickel. The $\mathrm{Pb} / \mathrm{U}$ ratio is high in the Uravan mineral belt area, at the Monument No. 2 mine, at the Happy Jack mine, and at Temple Mountain. Zinc distribution is generally inverse to cobalt, nickel, and lead.

\section{Possible guides to large deposits}

Cobalt, nickel, lead, and zine seem to be "common denominators" between ores of different stratigraphic position. The distribution patterns of these four metals seem to have consistent relations to the areas containing the largest mines in the Morrison and Shinarump formations. The following ratios are suggested as possible guides to areas containing -larger-than-2verage ore depositis:

1. $\mathrm{Pb} / \mathrm{U}$ greater than 1

2. $\mathrm{Pb} / \mathrm{Zn}$ greater than 10

3. $\mathrm{Zn} /$ geometric mean of $\mathrm{Co}$, and $\mathrm{Ni}$ less than $\mathbf{1 0}$ 
Table 8A.--Spectrographic analyses of barren Salt Wash sandstones Colorado localities: Horseshoe Bend and Tenderfoot Mesa I/

Elements

$\begin{array}{ccccc} & \text { Samples } & & & \\ 3 & 4 & 5 & 6 & 1 \\ 0 & 0 & 0 & 0 & 0 \\ * & * & * & * & * \\ 0.001 & * & * & * & * \\ 1 & 1 & 1 & 1 & 1 \\ 2- & 2- & 2- & 2- & 2- \\ 0 & 3+ & 3+ & 0 & 0 \\ 3- & 4 & 3- & 4+ & 4- \\ 3 & 3- & 3- & 3- & 3 \\ 4 & 4- & 4+ & 4- & 4- \\ 2 & 2 & 2+ & 2- & 2- \\ 8.6 & * & * & * & * \\ 4 & 3- & 3- & 3 & 3- \\ 3 & 4+ & 4+ & 3- & 4 \\ 5+ & 5 & 4- & 5 & 5- \\ 4 & 4 & 4- & 4 & 4 \\ 5- & 4- & 5 & 4- & 4- \\ 6- & 6+ & 6+ & 6+ & 5- \\ 0 & 0 & 0 & 0 & 0 \\ 0 & 0 & 0 & 0 & 0 \\ 0 & 0 & 0 & 0 & 0 \\ 0 & 0 & 0 & 0 & 0 \\ 0 & 0 & 0 & 0 & 0 \\ 0 & 0 & 0 & 0 & 0 \\ 0 & 5- & 5- & 6+ & 6+ \\ <0.05 & * & * * & * & * * \\ 0 & 0 & 0 & 0 & 0 \\ 0 & 0 & 0 & 0 & 0 \\ 6+ & 5- & 5- & 5- & 5- \\ 0 & 0 & 0 & 0 & 0 \\ 0 & 0 & 0 & 0 & 0 \\ 0 & 0 & 0 & 0 & 0 \\ 0 & 0 & 0 & 0 & 0 \\ 0 & 0 & 0 & 0 & 0 \\ 0 & 6- & 6- & 6- & 6- \\ & 0 & & & \\ 0 & 0 & 0\end{array}$

1/ Samples furnished by R.A. Cadigan.

1 Horseshoe Bend locality, Colo.; sec.31, T. 43 No, R. 17 W., and sec.6, T. $42 \mathbb{N}_{\circ}, R_{0} 17 W_{\circ}, \mathbb{N}_{\circ} M_{\circ} P_{\circ} M_{\circ} ; 3 \mathrm{ft}$ above base of Salt Wash sandstone member $(\mathrm{L}-366, \mathrm{D})$.

2 Same, $70 \mathrm{ft}$. above base $(\mathrm{L}-354, \mathrm{D})$.

3 Same, $225 \mathrm{ft}$. above base ( $\mathrm{L}-356, \mathrm{D})$.

4 Tenderfoot Mesa, secs. 17 and 20, T. 51 No, R. 18 Wo, N.M.P.M.; 50 feet above base of Sa.It Wash sandstone member ( $\mathrm{L}-25, \mathrm{D})$.

5 Same, 90 feet above base of Salt Wash sandstone member (L-26, D).

6 Same, 175 feet above base of Salt Wash sandstone member (L-27, D).

7 same, 255 feet above base of Sa.It Wash sandstone member (L-28, D). 
Table 8B.--Spectrographic analyses of barren Sa.lt Wash sandstones Colorado locallities: Dolores group of mines, Club mine, and Calamity No. 13 mine I/

\section{Elements}

\begin{tabular}{|c|c|c|c|c|c|}
\hline & $\underline{8}$ & 2 & .10 & 11 & 12 \\
\hline U & $\begin{array}{l}0 \\
*\end{array}$ & 0 & 0 & $\begin{array}{l}0 \\
*\end{array}$ & 3 \\
\hline $\mathrm{eU}_{3} \mathrm{O}_{8} \%$ & 0.002 & 0.001 & 0.000 & 0.001 & * \\
\hline $\mathrm{Si}$ & 1 & 1. & 1 & 1. & 1 \\
\hline $\mathrm{Al}$ & $2-$ & $2=$ & $2=$ & $2-$ & $2+$ \\
\hline $\mathrm{K}$ & $2-$ & 2.- & 0 & $2-$ & $3+$ \\
\hline $\mathrm{Na}$ & 4 & 4 & 4- & 4 & * \\
\hline $\mathrm{Fe}$ & 3 & 3 & 3 & 3 & 2 \\
\hline Mn & $4-$ & $4=$ & 4 - & 4 & 4 \\
\hline $\mathrm{Ca}$ & $2-$ & 2- & $2-$ & 2 & 2. \\
\hline $\mathrm{CacO}_{3} \%$ & 7.9 & 4.8 & 3.7 & 7.3 & * \\
\hline $\mathrm{Mg}$ & $2-$ & 3 & $3+$ & 2- & $2-$ \\
\hline $\mathrm{Ba}$ & 4 & 4 & 4 & 4 & $4+$ \\
\hline$S r$ & 5 & $5=$ & $5-$ & 5- & 4 \\
\hline Ti & 4 & 4 & 4 & $3-$ & 3 \\
\hline $\mathrm{Zx}$ & 5 & 4 & 4 & 4 & 5 \\
\hline $\mathrm{Cr}$ & 6. & $5=$ & $6-$ & $5=$ & $5+$ \\
\hline Ga & 0 & 0 & 0 & 0 & 0 \\
\hline Sc & 0 & 0 & 0 & 0 & 0 \\
\hline$Y$ & 0 & 0 & 0 & 5- & 0 \\
\hline $\mathrm{La}$ & 0 & 0 & 0 & 0 & 0 \\
\hline $\mathrm{Be}$ & 0 & 0 & 0 & 0 & 0 \\
\hline B & 5- & 5 & 0 & 5- & $5-$ \\
\hline V & 5 & 5 & 5 & 5 & $3-$ \\
\hline $\mathrm{V}_{2} \mathrm{O}_{5} \%$ & $<0.05$ & $<0.05$ & $<0.05$ & $<0.05$ & * \\
\hline Ni & 0 & 0 & 0 & 0 & 0 \\
\hline Co & 0 & 0 & 0 & 0 & 0 \\
\hline Cu & 5- & 6 & 6 & $6+$ & $5-$ \\
\hline $\mathrm{Pb}$ & 0 & 0 & 0 & 0 & $4-$ \\
\hline $\mathrm{Zn}$ & 0 & 0 & 0 & 0 & $3-$ \\
\hline $\mathrm{Cd}$ & 0 & 0 & 0 & 0 & 0 \\
\hline Mo & 0 & 0 & 0 & 0 & 5 \\
\hline As & 0 & 0 & 0 & 0 & 0 \\
\hline $\mathrm{Ag}$ & 0 & 0 & 0 & 0 & 0 \\
\hline
\end{tabular}

1/ Samples 9-11 furnished by R.A. Cadigan; samples 12 and 13 furnished by L。R. Stieff and T.W. Stern.

8 Dolores mine group, Colo., secs. 19 and 30, T。 48 N., R. 17 W., N.M.P.M.; 4 feet above base of Salt Wash sandstone member ( $\mathrm{L}-14, \mathrm{D}$ ).

9 Same; 45 feet above base of Salt Wash sandstone member ( $L-15, D)$.

10 Same; 223 feet above base of Sa.1.t Wash sandstone member ( L-18, D).

11 Same; 235 feet above base of Salt Wash sandstone member (L-19, D).

12 Club mine, Colo., sec. $33, T_{0} 48$ No, R。 17 W., N.M.P.M., (LRS-57-48, W).

13 Calamity No. 13 mine, Colo., sec. 1.1, T. 50 No, R. 18 W., N.M.P.M.; near ore, (TWS $-5-49$, W). 
Table 8C.--Spectrographic analyses of barren Salt Wash sandstones Colorado localities: Placerville and Skein Mesa I/

Elements

Samples

\begin{tabular}{|c|c|c|c|c|c|c|}
\hline & 14 & 15 & 16 & 17 & 18 & 19 \\
\hline $\mathrm{U}$ & 0 & 0 & 0 & 0 & 0 & 0 \\
\hline $\mathrm{U}_{3} \mathrm{O}_{8} \%$ & * & * & * & * & * & * \\
\hline $\mathrm{eU}_{3} \mathrm{O}_{8} \%$ & * & * & * & * & $*$ & * \\
\hline Si & $i$ & 1 & 1 & 1 . & 1 & 1 \\
\hline A.1. & $2-$ & $2-$ & $3+$ & $2-$ & 3 & $3-$ \\
\hline $\mathrm{K}$ & 0 & $2-$ & 0 & $2-$ & 0 & 0 \\
\hline $\mathrm{Na}$ & 4- & $3-$ & $4-$ & $3-$ & 4- & $3-$ \\
\hline $\mathrm{Fe}$ & $3-$ & $3-$ & $3-$ & $3-$ & $3-$ & 3- \\
\hline Mn & $4-$ & 4 & 4. & 40 & $4-$ & 4 \\
\hline $\mathrm{Ca}$ & $2+$ & 2. & 2 & 2 & 2 & 2 \\
\hline $\mathrm{CaCO}_{3} \%$ & $*$ & $*$ & * & * & * & * \\
\hline $\mathrm{Mg}$ & $3-$ & $2-$ & 3 & $2-$ & $2-$ & 2- \\
\hline $\mathrm{Ba}$ & $3-$ & 4 & 4 & $3-$ & $4-$ & 4 \\
\hline $\mathrm{Sr}$ & $5+$ & $5-$ & 6 & $5-$ & $5-$ & $5-$ \\
\hline $\mathrm{T} i$ & 4 & 4 & 4- & 4 & $4-$ & \\
\hline $\mathrm{Zr}$ & 4- & 4- & 5 & $4-$ & 5 & 5 \\
\hline $\mathrm{Cr}$ & $6+$ & 5- & 6 & $5-$ & $6+$ & 5- \\
\hline $\mathrm{Ga}$ & 0 & 0 & 0 & 0 & 0 & 0 \\
\hline Se & 0 & 0 & 0 & 0 & 0 & 0 \\
\hline$Y$ & 0 & 0 & 0 & 0 & 0 & 0 \\
\hline La & 0 & 0 & 0 & 0 & 0 & 0 \\
\hline $\mathrm{Be}$ & 0 & 0 & 0 & 0 & 0 & 0 \\
\hline B & 0 & 0 & 0 & 0 & 0 & 0 \\
\hline V & 5- & 5 & $5-$ & $5-$ & 6 & 5- \\
\hline $\mathrm{V}_{2} \mathrm{O}_{5} \%$ & $*$ & * & * & * & * & \\
\hline $\mathrm{NI}$ & 0 & 0 & 0 & 0 & 0 & 0 \\
\hline Co & 0 & 0 & 0 & 0 & 0 & 0 \\
\hline $\mathrm{Cu}$. & $5-$ & 6 & $5-$ & 6 & 6 & 6 \\
\hline $\mathrm{Pb}$ & 0 & 0 & 0 & 0 & 0 & 0 \\
\hline $\mathrm{Zn}$ & 0 & 0 & 0 & 0 & 0 & 0 \\
\hline $\mathrm{Cd}$ & 0 & 0 & 0 & 0 & 0 & 0 \\
\hline Mo & 0 & 0 & 0 & 0 & 0 & 0 \\
\hline As & 0 & 0 & 0 & 0 & 0 & 0 \\
\hline $\mathrm{Ag}$ & $6-$ & $6-$ & $6-$ & $6-$ & $6-$ & $0-$ \\
\hline
\end{tabular}

I/Samples furnished by R. A. Cadigan

14 Placerville, Colo., sec。29, T. 44 N., R. 11 W., N.M.P.M. (L-351, D). For analysis of heavy mineral content, see no. 5 , table 9.

15 Skein Mesa, Colo., sees. 9 and $16, T_{0} \cdot 46$ N., R. 18 W., N.M.P.M., (190 feet above base of Salt Wash sandstone member.) (L-588, D) For analysis of heavy mineral content, see no. 3, table 9.

16 Same; 282 feet above base of Salt Wash sandstone member ( $L-2, D)$.

17 Same; 245 feet above base of Salt Wash sandstone member (I-582, D).

18 Same; 20 feet above base of Salt Wash sandstone member (L-599, D).

19 Same; 30 feet above base of Sa.1t Wash sandstone member ( $\mathrm{L}-603, \mathrm{D}$ ). 
Table 8D.--Spectrographic analyses of barren Salt Wash sandstones New Mexico and Utah localities I/

Elements

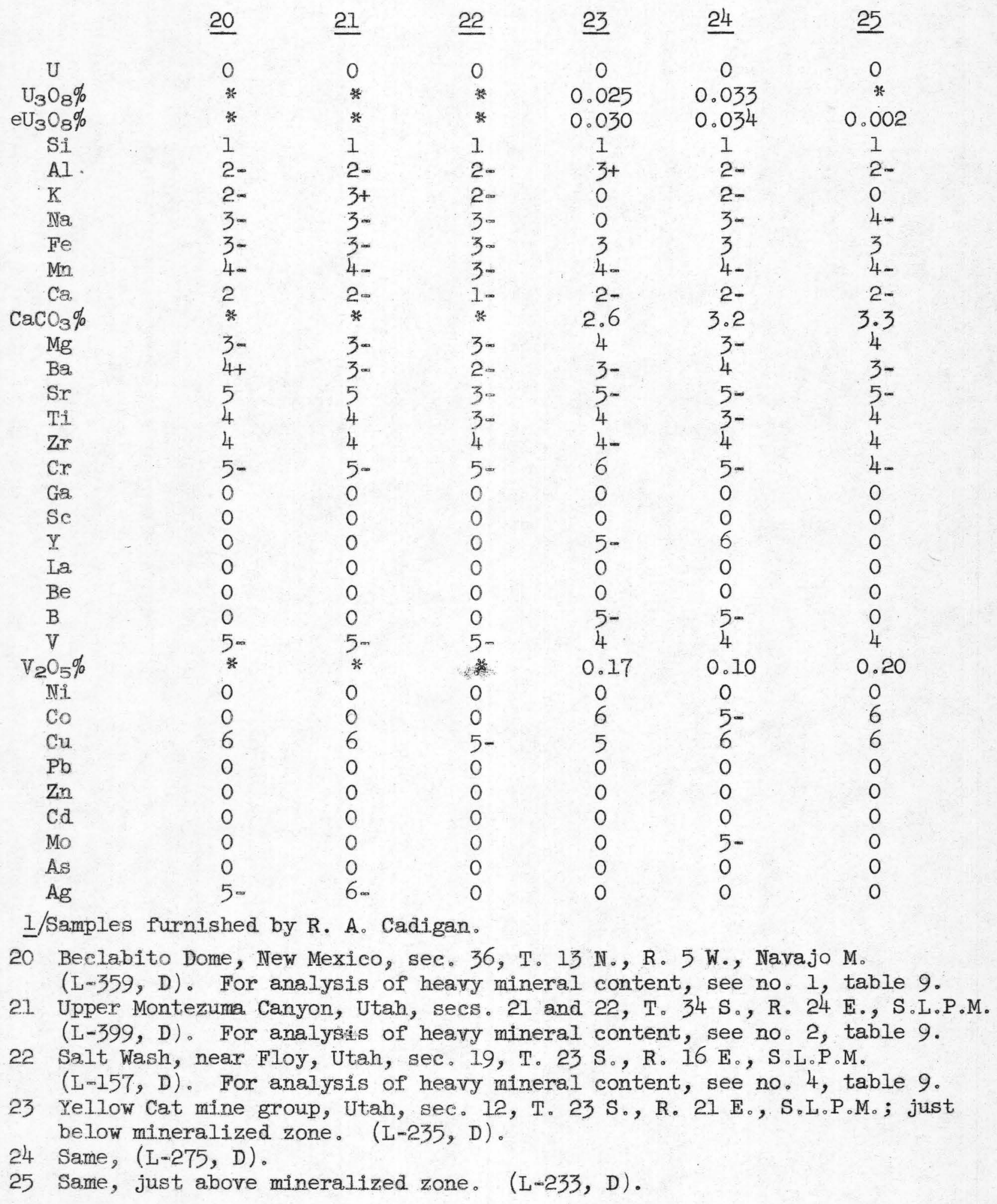


Table 9.--Spectrographic analyses of heavy mineral fraction I] from barren Salt Wash sandstones

Elements

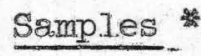

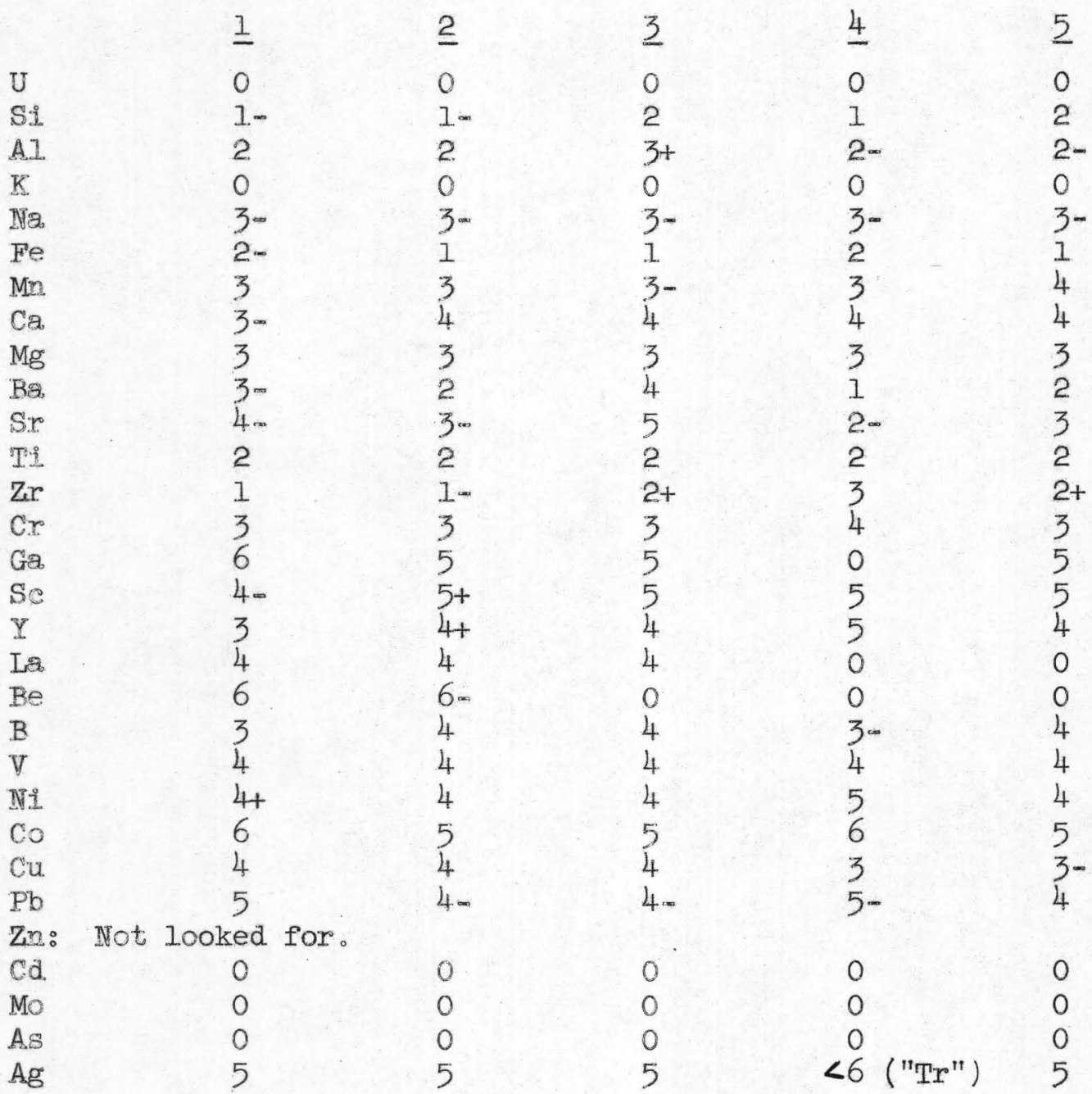

* Samples and descriptions furnished by R. A. Cadigan

1 Beclabito Dome, New Mexico $(\mathrm{L}-359, \mathrm{D})$. Nonopaque minerals, 83 percent: zircon, garnet, tourma.line, rutile, anatase. opaque minerals, 17 percent: leucoxene, ilmenite, magnetite.

2 Upper Montezuma Canyon, Utah $(\mathrm{L}-399, \mathrm{D})$. Nonopaque minera.ls, 25 percent: zircon, barite, tourmaline, garmet, rutile. Opaque minerals, 75 percent: i.lmenite, magnetite, leucoxene.

3 Skein Mesa, Colo. ( $\mathrm{L}-588, \mathrm{D})$. Nonopaque minerals, 17 percent: tourmaline, zircon, anatase, biotite, rutile. opaque minerals, 83 percent: ilmenite, magnetite, leucoxene.

4 Salt Wash, near Floy, Utah $(\mathrm{L}-157, \mathrm{D})$. Nonopaque minerals, 85 percent: barite, tourmaline, zircon. Opaque minerals, 15 percent: ilmenite, leucoxene.

5 From Placerville, Colorado $(L-351, D)$. Nonopaque minerals, 40 percent: zircon, tourmaline, barite, anatase, rutile. Opaque minerals, 60 percent: magnetite, leucoxene, ilmenite. Brass or bronze contamination noted.

1. Specific grayity above 2.9. 
Table 10.--Spectrographic analyses of barren SaIt Wash (midstones and shales) I/

Eilements

\begin{tabular}{|c|c|c|c|c|c|}
\hline & $\underline{I}$ & $\underline{2}$ & 3 & 4 & 5 \\
\hline $\mathrm{U}$ & 0 & 0 & 0 & 0 & 0 \\
\hline Si & 1 & 1 & 1 & 1 & 1 \\
\hline A.I & 1 & 1 & 1 & $I$ & 1 \\
\hline $\mathrm{K}$ & $2-$ & 2 & 2 & 2 & $2+$ \\
\hline $\mathbb{N g}$ & 3 & $2-$ & $2-$ & 2 & $2-$ \\
\hline $\mathrm{Fe}$ & 2 & $2+$ & $2+$ & $2+$ & 2 \\
\hline $\mathrm{Mn}$ & 4 & 4- & $4-$ & 5 & $4-$ \\
\hline $\mathrm{Ca}$ & $2+$ & 2 & 2 & $2-$ & 3 \\
\hline $\mathrm{Mg}$ & 3 & $2-$ & $2-$ & $2-$ & 2 \\
\hline $\mathrm{Ba}$ & $4+$ & 4 & 4 & $5+$ & 4 \\
\hline Sr & $4-$ & 4 & $4+$ & $4-$ & 5 \\
\hline Ti & 4 & $4+$ & 4 & $4+$ & $4+$ \\
\hline $\mathrm{Zr}$ & $5+$ & $5+$ & $4-$ & 4 & $4-$ \\
\hline $\mathrm{Cr}$ & 5 & $5+$ & 5 & $5-$ & $5+$ \\
\hline $\mathrm{Ga}$ & 5 & 5 & $5+$ & 5 & $5+$ \\
\hline $\mathrm{Sc}$ & 0 & $4-$ & 4 & 4 & 0 \\
\hline$Y$ & $5-$ & $5-$ & 0 & 0 & $5-$ \\
\hline Ia & 0 & 0 & 0 & 0 & $5-$ \\
\hline $\mathrm{Be}$ & 0 & 0 & 0 & 0 & 0 \\
\hline B & 0 & 0 & 0 & 0 & 0 \\
\hline V & 5 & 5 & 5 & 5 & 4 \\
\hline $\mathrm{Ni}$ & $5-$ & 5 & $5-$ & $5-$ & $5-$ \\
\hline Co & 0 & 0 & 0 & 0 & 0 \\
\hline Cu & $5-$ & $5-$ & 50 & $5-$ & 5 \\
\hline $\mathrm{Pb}$ & 0 & $5-$ & 0 & $5+$ & 5 \\
\hline $\mathrm{Zn}$ & 0 & 0 & 0 & 0 & 0 \\
\hline cd & 0 & 0 & 0 & 0 & $\theta$ \\
\hline Mo & 0 & 0 & 0 & 0 & 6 \\
\hline Âs & 0 & 0 & 0 & 0 & 0 \\
\hline $\mathrm{Ag}$ & 0 & 0 & 0 & 0 & 0 \\
\hline
\end{tabular}

1/Ana.lyses furnished by Alice D. Weeks, from samples used for stratigraphic clay studies.

1. Woodside anticline, Utah, sec.5, T。 19 S., R. 14 W., S.I.P.M. (L-533, W)。

2 Same; $(\mathrm{L}-534, \mathrm{~W})$.

3 Salt Wash, near Floy, Utah, sec. 19, T. 23 S., R. 16 E., S.L.P.M. (L-451, W)。

4 Same; $(L-450, W)$.

5 Same; $(I-449, W)$.

6 Same: $(\mathrm{L}-448, \mathrm{~W})$. 
Table 10.--Continued

\section{E.lements}

\begin{tabular}{|c|c|c|c|c|c|}
\hline & $\underline{6}$ & $I$ & $\underline{8}$ & 2 & 10 \\
\hline $\mathrm{U}$ & 0 & 0 & 0 & 0 & 0 \\
\hline Si & I. & 1. & 1 & 1 & 1 \\
\hline AII & 1 & 1 & 1 & 1 & $2+$ \\
\hline $\mathrm{K}$ & 2 & 2 & 2 & 2 & 2- \\
\hline $\mathrm{Na}$ & 3 & 3 & 3 & 3 & \\
\hline $\mathrm{Fe}$ & 2 & $2+$ & 2.t & $2+$ & \\
\hline $\mathrm{M} 23$ & 4 & 4 & 4 & 4- & $5-$ \\
\hline $\mathrm{Ca}$ & $2+$ & 2 & 2 & 2 & $=$ \\
\hline Mg & $2-$ & $2-$ & $2-$ & $2-$ & \\
\hline $\mathrm{Ba}$ & 4 & 4 & $5+$ & 4 & \\
\hline $\mathrm{S} r$ & 4 & 4. & 4 & 4 & $4+$ \\
\hline $\mathrm{Ti}$ & $4 t$ & $4+$ & $4+$ & $4+$ & \\
\hline$Z_{r}$ & $4-$ & 5 & $4-$ & 5 & \\
\hline $\mathrm{Cr}$ & 5 & $5-$ & 5 & $5+$ & \\
\hline Ġ & 5 & 5 & 5 & $5-$ & \\
\hline $\mathrm{Se}$ & $4=$ & 4. & $4-$ & $4-$ & \\
\hline$Y$ & $5-$ & 0 & 0 & 5 & \\
\hline L8 & 0 & 0 & 0 & 0 & \\
\hline $\mathrm{Be}$ & 0 & 0 & 0 & 0 & 0 \\
\hline B. & 0 & 0 & 0 & 0 & \\
\hline$V$ & $5+$ & $5+$ & 4 & 5 & \\
\hline Ni. & 5 & 5- & 5 & $5-$ & \\
\hline Co & 0 & $5+$ & 0 & 0 & \\
\hline $\mathrm{Cu}$ & $5-$ & 5 & 50 & $5-$ & \\
\hline $\mathrm{Pb}$ & 0 & 0. & 0 & 0 & \\
\hline $\mathrm{Zn}$ & 0 & 0 & 0 & 0 & \\
\hline $\mathrm{Cd}$ & 0 & 0 & 0 & 0 & \\
\hline Mo & 0 & 0 & 0 & 0 & \\
\hline $\mathrm{As}$ & 0 & 0 & 0 & 0 & \\
\hline $\mathrm{Ag}$ & 0 & 0 & 0 & 0 & \\
\hline
\end{tabular}

6 Kane Springs, Utah, sec. 7, T. 28 S。, R. 23 E., S.L.P.M. (L-480, W).

7 La Sal Creek, Utah, sec. 32, T. 28 S。, R. 26 E., S.L.P.M. (L-475, W)。

8 Dolores mine group, Colo., secs. 19 and 30, T. 48 N., R。 17 W., N.M.P.M. $(\mathrm{L}-47 ., \mathrm{W})$.

9 Unaweep Canyon, Colo., secs. 1 and 2, T. 14 S., R. 100 Wo, 6th P.M. $(\mathrm{L}-456, \mathrm{~W})$.

10 Escalante Forks, Colo., sec。34, T. 51 N。, R。 14 W., N.M.P.M. (L-46I, W). 
Table IIA.--Spectrographic analyses of intrusive igneous rocks on the Colorado Plateau. Diorite and monzonite porphyries from the La Sal Mountains, Utah.

Elements

Samples I/

\begin{tabular}{|c|c|c|c|c|c|c|}
\hline & $\underline{1}$ & $\geqq$ & $\underline{3}$ & $\underline{4}$ & 2 & $\underline{6}$ \\
\hline $\mathrm{U}$ & 0 & 0 & 0 & 0 & 0 & 0 \\
\hline $\mathrm{U}_{3} \mathrm{O}_{8} \%$ & 0.001 & 0.000 & 0.000 & 0.000 & 0.000 & 0.001 \\
\hline $\mathrm{eU}_{3} \mathrm{O}_{8} \%$ & .002 & .001 & .002 & .001 & .002 & .002 \\
\hline Si & Not looked & for. & & & & \\
\hline$\frac{\mathrm{A} I}{\mathrm{~K}}$ & 2 & 2 & 2 & 2 & 2 & 2 \\
\hline $\begin{array}{l}\mathrm{K} \\
\mathrm{N} a\end{array}$ & Not looked & for. & & & & \\
\hline $\mathrm{Na}$ & $I$ & 1 & 1 & 1 & 1 & 1 \\
\hline $\mathrm{Fe}$ & 2 & 2 & 2 & 2 & 2 & 2 \\
\hline Mn & 3 & 4 & 4 & 3 & 4 & 3 \\
\hline $\mathrm{Ca}$ & 2 & 2 & 2 & 2 & 2 & 2 \\
\hline $\mathrm{Mg}$ & 2 & 2 & 2 & 2 & 2 & 2 \\
\hline $\mathrm{Ba}$ & 3 & 4 & 3 & 3 & 3 & 3 \\
\hline Sx & 3 & 4 & 3 & 3 & 3 & 3 \\
\hline Ti & 3 & 3 & 3 & 3 & 3 & 3 \\
\hline $\mathrm{Zr}$ & 4 & 4 & 4 & 4 & 4 & 4 \\
\hline $\mathrm{Cr}$ & 5 & 6 & 5 & 5 & 5 & 5 \\
\hline $\mathrm{G} \approx$ & 5 & 5 & 5 & 5 & 5 & 5 \\
\hline Sc & 5 & 5 & 5 & 5 & 5 & 5 \\
\hline$Y$ & 5 & 5 & 5 & 5 & 5 & 5 \\
\hline $\mathrm{La}$ & 5 & 0 & 0 & 0 & 0 & 0 \\
\hline $\mathrm{Be}$ & 6 & 6 & $<6(" T r ")$ & 6 & 6 & 6 \\
\hline B & 0 & 0 & 0 & 0 & 0 & 0 \\
\hline V & 4 & 5 & 4 & 4 & 4 & 4 \\
\hline$N i$ & 0 & 0 & 5 & 0 & 5 & 0 \\
\hline Co & 5 & 0 & 5 & 0 & 5 & 5 \\
\hline $\mathrm{Cu}$ & 5 & 5 & 5 & 6 & 5 & 5 \\
\hline $\mathrm{Cu}, \mathrm{ppm}$ & 30 & 30 & 40 & 35 & 45 & 35 \\
\hline $\mathrm{Pb}$ & 0 & $<5\left(" T r^{n}\right)$ & 0 & 0 & 0 & $\angle 5$ (" $^{\prime \prime}$ \\
\hline $\mathrm{Pb}$, ppm & 10 & 25 & 15 & 50 & 15 & 40 \\
\hline $\mathrm{Zn}$ & 0 & 0 & 0 & 0 & 0 & 0 \\
\hline $\mathrm{Zn}, \mathrm{ppm}$ & 40 & 30 & 40 & 20 & 50 & 85 \\
\hline $\mathrm{Cd}$ & 0 & 0 & 0 & 0 & 0 & 0 \\
\hline Mo & 0 & 0 & 0 & 0 & 0 & 0 \\
\hline As & 0 & 0 & 0 & 0 & 0 & 0 \\
\hline $\mathrm{Ag}$ & 0 & 0 & 0 & 5 & 0 & 6 \\
\hline
\end{tabular}

If Analyses and descriptions furnished by C. B. Hunt.

I Schuman Canyon laccolith. Unaltered diorite porphyry. (RII, D).

2 Grouse Hill laccolith. Slightly altered diorite porphyry. (R12, D)。

3 Oregon Park laccolith. Unaltered diorite porphyry. (RIO, D).

4 On divide between Miners and Bachelor basins. Diorite porphyry with pyritic alteration. (R2, D)。

5 Same locality。 Unaltered diorite porphyry. (R3, D).

6 Same locality. Monzonite porphyry. (RI, D). 
Table 11B,--Spectrographic analyses of intrusive igneous rocks on the Colorado Plateau. Syenite and granite porphyries, from the La Sa.l Mountains, Utah, and the Carrizo Mountains, Arizona

Elements

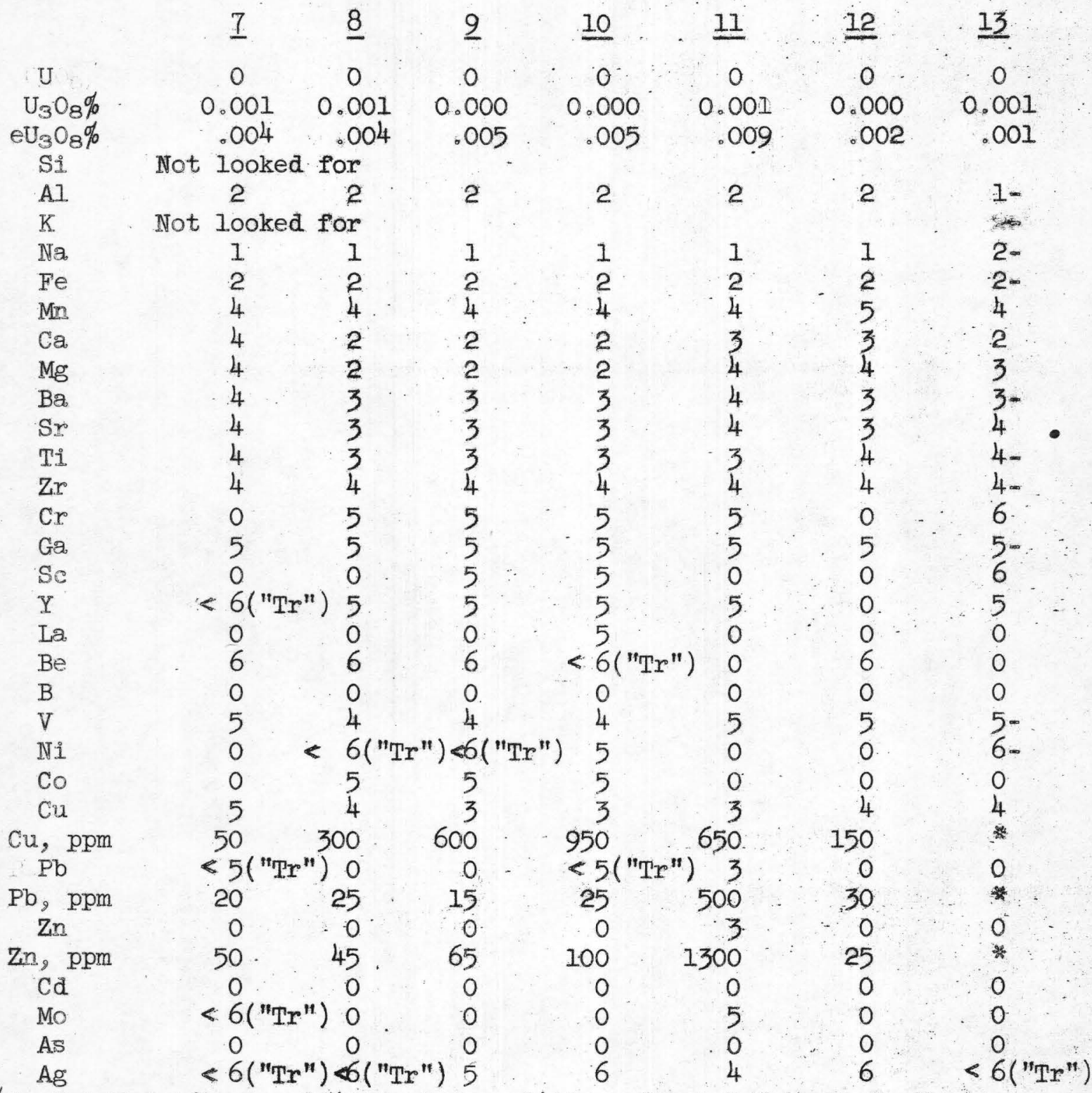

1/ La Sal Mountains analyses and descriptions furnished by C. B. Hunt

7 Near Venus mine, Bachelor basin. Coarse syenite porphyry dike. (R8)

8 Same locality. Unaltered syenite porphyry.

9. Cirque wall above High Ore mine, Bachelor basin. Unaltered syenite porphyry, moderately coarse. (R4)

$102000 \mathrm{ft}$. SE of High Ore mine. Fine grain syenite porphyry. (R9)

11 Near 9 above. Similar rock (syenite porphyry) but with pryitic alteration. (R5)

12 Mineral Mountain. Feldspar phenocrysts from coarse syenite porphyry. (RI3)

Carrizo Mountains. Aample and description furnished by J. D. Strobell.

13 Isolated laccolith, south end Carrizo Mountains. "Rhyolite porphyry". 
Table 12.--Spectrographic analyses of metalliferous vein deposits from the La Sal Mountains, Utah

Elements

Samples I/

\begin{tabular}{|c|c|c|c|c|c|}
\hline & $\underline{I}$ & $\underline{2}$ & $\underline{3}$ & $\underline{4}$ & 5 \\
\hline U & 0 & 0 & 0 & 0 & 0 \\
\hline $\mathrm{U}_{3} \mathrm{O}_{8} \%$ & 0.001 & 0.001 & $\angle 0.001$ & 0.002 & 0.002 \\
\hline $\mathrm{eU}_{3} \mathrm{O}_{8} \%$ & .004 & .002 & .001 & .004 & .002 \\
\hline Si & 1 & 1 & 1. & 1 & 1 \\
\hline A. 1 . & 2 & 2 & 2- & $2+$ & 1- \\
\hline $\mathrm{K}$ & 2 & 2 & 2 & $2-$ & 2 \\
\hline Na & $2-$ & $3+$ & $3+$ & 2 & 2 \\
\hline $\mathrm{Fe}$ & $2+$ & 2 & 1 & 2 & 2 \\
\hline Mn & 4- & $4 \infty$ & 4 & 4- & 4- \\
\hline $\mathrm{Ca}$ & $3+$ & 3 & $2+$ & 2 & $2-$ \\
\hline $\mathrm{Mg}$ & 3 & $3-$ & $1 \infty$ & $3+$ & 3 \\
\hline $\mathrm{Ba}$ & 4 & $3=$ & 5 & 4 & 4 \\
\hline Sr & 5 & 4 & 5 & 4- & 4 \\
\hline $\mathrm{Ti}$ & $3-$ & $3=$ & $3=$ & $3-$ & $3=$ \\
\hline $\mathrm{Zr}$ & 4 & 5 & 4 & 5 & 4- \\
\hline $\mathrm{Cr}$ & 5 & 5 & 5 & 5 & 5 \\
\hline $\mathrm{Ga}$ & $5-$ & $5-$ & 5 & $5-$ & 5- \\
\hline Se & 6 & 6 & $\begin{array}{l}6- \\
5-\end{array}$ & 5 & 5 \\
\hline$Y$ & $\begin{array}{l}5- \\
0\end{array}$ & 5- & 50 & 5 & 5 \\
\hline La & 0 & 0 & 0 & $4+$ & $5+$ \\
\hline $\mathrm{Be}$ & 0 & 0 & 0 & 0 & 0 \\
\hline B & 0 & 0 & 0 & 0 & 0 \\
\hline $\mathrm{Ce}$ & 0 & 0 & 0 & 4 & $4 \ldots$ \\
\hline $\mathrm{V}$ & 4 & 4 & $4=$ & 4. & 4- \\
\hline Ni. & $5-$ & $5-$ & 4 & $6+$ & 5- \\
\hline Co & 6 & 6 & 4- & 5 & 5 \\
\hline $\mathrm{Cu}$ & 1 & 1 & 3 & 2 & $3-$ \\
\hline $\mathrm{Pb}$ & $4+$ & $4+$ & 0 & 0 & 0 \\
\hline $\mathrm{Zn}$ & 0 & 0 & 0 & 0 & 0 \\
\hline cd. & 0 & 0 & 0 & 0 & 0 \\
\hline Mo & 5 & $5-$ & $5-$ & $4-$ & 5- \\
\hline As & 0 & 0 & 0 & 0 & 0 \\
\hline $\mathrm{Ag}$ & $4+$ & 4 & $<\sigma(" T r ")$ & 5 & $<6(" T r ")$ \\
\hline $\mathrm{Bi}$ & $4+$ & $4+$ & $0^{\circ}$ & 0 & 0 \\
\hline$S n$ & 5- & $5-$ & $5-$ & 5- & 5- \\
\hline
\end{tabular}

1. Samples collected by E. J。 McKay (EM-) and E. M. Shoemaker (EMS-)

1. Beaver Basin mine. Composite grab sample; sulfides in granite porphyroy (EMS $-51-10, D)$

2 Same, (EMS-51-9, D)

3 Fowler mine, Miners basin. Channel sample; silicate alteration zone (EMS $-5.1-3, D)$

4 Fowler mine, Miners basin. Channel sample; oxidized crush zone (EMS-51-4, D)

5 MIF no. 2 mine, Miners basin, Channel sample; oxidized crush zone, (EMS $-51-6, D)$ 
Table 12,-continued.

Elements

\begin{tabular}{|c|c|c|c|c|}
\hline & 6 & 7 & 8 & 2 \\
\hline U & 0 & 0 & 0 & 0 \\
\hline $\mathrm{U}_{3} \mathrm{O}_{8} \%$ & 0.001 & 0.001 & 0.001 & 0.003 \\
\hline $\mathrm{eU}_{3} \mathrm{O}_{8} \%$ & .007 & .008 & .001 & .004 \\
\hline Si & 1 & 1 & $1-$ & 1. \\
\hline AI & $1-$ & $2-$ & 2 & 2 \\
\hline $\mathrm{K}$ & 2 & $2 \infty$ & 0 & 2 \\
\hline N8. & 2 & 3 & 2 & 3 \\
\hline $\mathrm{Fe}$ & $2 \infty$ & $2+$ & 2 & 2 \\
\hline $\mathrm{Mn}$ & $3-$ & 4. & 4 & 5. \\
\hline Ca & $2-$ & 2 & 1 & 1 \\
\hline $\mathrm{Mg}$ & $3-$ & 3 & $4+$ & 4 \\
\hline $\mathrm{Ba}$ & $3-$ & 3 & 30 & $4-$ \\
\hline$S r$ & $4+$ & $4=$ & 3 & 4. \\
\hline$T 1$ & $3=$ & $4 \infty$ & $4+$ & $4-$ \\
\hline Zro & 4. & $5-$ & 6 & 6 \\
\hline $\mathrm{Cx}$ & 5 & 6 & 6 & 5 \\
\hline $\mathrm{Ga}$ & $5-$ & $6-$ & $6-$ & $6-$ \\
\hline Se & $6-$ & 6 & 5 & 0 \\
\hline$Y$ & 5 & 5 & 4 & 5 \\
\hline La & 4 & 40 & $4+$ & $4-$ \\
\hline $\mathrm{Be}$ & 0 & 0 & 0. & 0 \\
\hline B & 0 & 0 & 0 & 0 \\
\hline $\mathrm{Ce}$ & 4 & 4 & $\%$ & 0 \\
\hline$\nabla$ & 5 & $5+$ & 5 & $4-$ \\
\hline $\mathrm{NI}$ & 5 & $6+$ & $6+$ & $5-$ \\
\hline CO & 6 & 5. & 6 & $5-$ \\
\hline cu. & 3 & 10 & $4+$ & 2 \\
\hline $\mathrm{Pb}$ & $4+$ & 4 & 0 & 5 \\
\hline $\mathrm{Zn}$ & 3 & 3 & 0 & 0 \\
\hline $\mathrm{cd}$ & 0 & 0 & 0 & 0 \\
\hline Mo & 5 & $5=$ & 0 & 0 \\
\hline As & 0 & 0 & 0 & 0 \\
\hline $\mathrm{Ag}$ & 5 & 5 & $\angle 6\left(" \mathrm{Tr}_{\mathrm{r}}\right.$ ") & $5-$ \\
\hline$B i$ & 50 & $5+$ & 0 & 0 \\
\hline $\mathrm{Sn}$ & 0 & 5- & 0 & 0 \\
\hline
\end{tabular}

1. Samples collected by E. J. McKay (EM-) and E. M. Shoemaker (EMS-)

6 Dewey Tunnel, North Mountain. Channel sample; oxidized crush zone (EM-5.1-1, D)

7 High Ore mine, Bachelor basin. Channel sampleg sulfides in vein $($ EMSS $-51-7, D)$

8 MIF no. 2 mine, Miners basin. Channel sample; fluorite seam in oxidized zone (EMS-5I-5, D)

9 High Ore mine, Bachelor basin. Channel sample: fluorite in vein $($ FMS $-51-8)$. 
Table 13.--Spectrographic analyses of copper sulfide-sulfarsenide vein deposits in sandstone I/

\section{Samples}

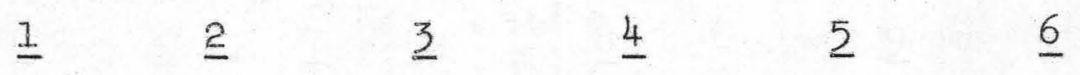

\begin{tabular}{|c|c|c|c|c|c|c|}
\hline $\mathrm{U}$ & 0 & 0 & 0 & 0 & 0 & 0 \\
\hline $\mathrm{U}_{3} \mathrm{O}_{8} \%$ & $<0.001$. & $<0.001$ & $<0.001$ & $<0.001$ & $<0.001$ & $<0.001$ \\
\hline $\mathrm{eU}_{3} \mathrm{O}_{8} \%$ & .002 & .002 & .002 & .001 & .001 & .001 \\
\hline Si. & 1 & 1 & 1 & 1 & 1 & $1-$ \\
\hline A.1. & $3=$ & $2-$ & 20 & $2-$ & $2 \infty$ & $2-$ \\
\hline $\mathrm{K}$ & $2-$ & $2-$ & $2-$ & $2-$ & $2-$ & $1-$ \\
\hline $\mathrm{Na}$ & 3 & 3 & 3 & 3 & 3 & $3-$ \\
\hline $\mathrm{Fe}$ & $3+$ & $2 \infty$ & 3 & 3 & 3 & $2-$ \\
\hline $\mathrm{Mn}$ & 6 & 4 & $5-$ & 4 & 4 & 4- \\
\hline $\mathrm{Ca}$ & 2 & $4+$ & 3 & 3 & 2- & 1. \\
\hline $\mathrm{Mg}$ & 3 & 3 & $3-$ & $3-$ & $3=$ & 3 \\
\hline $\mathrm{B \&}$ & $4+$ & 2 & 2 & 2 & $3-$ & 4 \\
\hline Sr & 4 & $4+$ & $4+$ & 4 & $5+$ & 5 \\
\hline Ti. & $3=$ & 4 & 4 & 4 & $3-$ & 4 \\
\hline Zre & 4 & 4 & $4 \infty$ & 4 & $4=$ & 4- \\
\hline $\mathrm{Cr}$ & 5 & 5 & $5 \cdots$ & 6 & 5 & 5- \\
\hline Ga & 0 & 0 & 0 & 0 & 0 & 0 \\
\hline Se & 0 & 0 & 0 & 0 & 0 & 0 \\
\hline$Y$ & 6 & 0 & 6 & 0 & 0 & 0 \\
\hline La & 0 & 0 & 0 & 0 & 0 & 0 \\
\hline $\mathrm{Be}$ & 0 & 0 & 0 & 0 & 0 & 0 \\
\hline B & $5-$ & 50 & 5 & $5=$ & $5-$ & $5-$ \\
\hline $\mathrm{Ce}$ & 0 & 0 & 0 & 0 & 0 & 0 \\
\hline V & 0 & 0 & 0 & 0 & $5-$ & 0 \\
\hline $\mathrm{Ni}$ & $6+$ & $5^{\circ}$ & $6+$ & 50 & $6-$ & 0 \\
\hline $\mathrm{CO}$ & 6 & 6 & 0 & 6 & 0 & 0 \\
\hline $\mathrm{Cu}$ & 2 & 10 & 1. & 2 & $1-$ & 2 \\
\hline $\mathrm{Pb}$ & 4 & 4 & 4 & 4 & 0 & $5+$ \\
\hline $\mathrm{Zn}$ & 3 & $3-$ & $3-$ & $3-$ & 0 & 0 \\
\hline $\mathrm{Cd}$ & 0 & 0 & 0 & 0 & 0 & 0 \\
\hline Mo & $4-$ & 0 & 0 & 0 & 0 & 0 \\
\hline As & 0 & 0 & 0 & 0 & 0 & 0 \\
\hline $\mathrm{Ag}$ & 5 & 4 & 4 & $4-$ & $4-$ & 5 \\
\hline $\mathrm{Bi}$ & 0 & 0 & 0 & 0 & 0 & 0 \\
\hline$S n$ & $5=$ & 0 & 0 & 0 & 0 & 0 \\
\hline
\end{tabular}

I. Samples co.1.lected by E.J. McKay.

1 Cliff Dweller mine, La Sa.1 Creek, Colo., sec.22, T. 47 N., R. 19 W., N.M.P.M. Channel sample (EM-51-6, D)。

2 Cashin mine, La Sal Creek, Colo., sec. 22, T。 47 N., R. 19 W., N.M.P.M. Channel sample; crush zone. (EM-51-5A, D).

3 Same. Channel sample; crush zone, adjacent to crush zone. (EM-51-5B, D).

4 Same. Channel sample; fault. (EM-51-4, D).

5 Sunrise mine, Paradox Va.1.ley, Colo., sec.23, T. 48 N., R. 19 W., N.M.P.M. Channel sample. $(E M-51-2, D)$.

6 Same. Grab sample of ore on dump; apparently from midale of fault breccia. $(E M-51-3, D)$. 
42

Table 13. - Continued.

Elements

Samples

\begin{tabular}{|c|c|c|c|c|}
\hline & 1 & $\underline{8}$ & 2 & 10 \\
\hline U & 0 & 0 & 0 & 0 \\
\hline $\mathrm{U}_{3} \mathrm{O}_{8} \%$ & $<0.001$ & $<0.001$ & $<0.001$ & 0.004 \\
\hline $\mathrm{eU}_{3} \mathrm{O}_{8} \%$ & .001 & .001 & .001 & .008 \\
\hline Si & $I$ & 1 & 1 & I- \\
\hline A. & $3-$ & $2-$ & $2-$ & $2=$ \\
\hline K & 0 & 0 & 0 & 0 \\
\hline $\mathrm{Na}$ & 0 & 0 & 0 & 0 \\
\hline $\mathrm{Fe}$ & 2- & 2 & 2- & $2-$ \\
\hline $\mathrm{Mn}$ & $4-$ & $4-$ & 3 & $6-$ \\
\hline $\mathrm{Ca}$ & $3=$ & $3-$ & $3-$ & $3+$ \\
\hline $\mathrm{Mg}$ & 6 & 4 & 4 & 4 \\
\hline $\mathrm{B}$. & $3-$ & $4-$ & $4 t$ & 4 \\
\hline Sr & $6-$ & 6 & 5 & 6 \\
\hline $\mathrm{Ti}$ & $4-$ & $4-$ & $4-$ & 4- \\
\hline $\mathrm{Zr}$ & $6-$ & $5 \infty$ & $5-$ & 5 \\
\hline $\mathrm{Cr}$ & 6 & 5 & $5=$ & $6-$ \\
\hline $\mathrm{Ga}$ & 0 & 0 & 0 & 0 \\
\hline Sc & 0 & 0 & 0 & 0 \\
\hline$Y$ & 0 & 5 & 5- & 0 \\
\hline La & 0 & 0 & 0 & 0 \\
\hline $\mathrm{Be}$ & 0 & 0 & 0 & 0 \\
\hline B & 0 & 0 & 0 & 0 \\
\hline $\mathrm{Ce}$ & 0 & 0 & 0 & 0 \\
\hline $\mathrm{V}$ & 0 & 0 & 0 & 0 \\
\hline $\mathbb{N i}$ & $5=$ & $5-$ & $5-$ & $6+$ \\
\hline Co & 0 & 6. & $6=$ & 0 \\
\hline $\mathrm{Cu}$ & 1 & 2 & 3 & $1-$ \\
\hline $\mathrm{Pb}$ & $6-$ & $6=$ & 0 & $4+$ \\
\hline $\mathrm{Zn}$ & 0 & 0 & 0 & 3 \\
\hline $\mathrm{cd}$ & 0 & 0 & 0 & 0 \\
\hline Mo & $5-$ & $5 \infty$ & $5-$ & 4 \\
\hline As & 0 & 0 & 0 & $2-$ \\
\hline$A B$ & 5 & $5 \infty$ & 6 & 4 \\
\hline $\mathrm{BI}$ & 0 & 0 & 0 & 0 \\
\hline $\mathrm{Sn}$ & 0 & 0 & 0 & 0 \\
\hline
\end{tabular}

7 Big Indian mine, Lisbon Valley, Utah, sec.33, T. 29 S., R. 24 E., S.L.P.M. Grab sample of ore on dump. (EM-51-12, D).

8 Same. Channel sample; in open cut east of mill. (EM-5I-II, D).

9 Same. Channel sample; in open cut east of mill. (EM-51-10, D).

10 Copper Rivet mine, Sinbad Valley, Colo., sec. 3, T. 49 N., R. 19 W., N.M.P.M。 Grab sample of ore from dump。 (EM-51-7, D). 
Table 14.--Spectrographic analyses of uranium-bearing vein deposits of unusua.l types.

Samples I/

\begin{tabular}{|c|c|c|c|c|}
\hline & $\underline{I}$ & $\underline{2}$ & 3 & $\underline{4}$ \\
\hline $\mathrm{U}$ & 0 & 0 & 0 & 0 \\
\hline $\mathrm{U}_{3} \mathrm{O}_{8} \%$ & 0.025 & 0.001 & 0.002 & 0.012 \\
\hline $\mathrm{eU}_{3} \mathrm{O}_{8} \%$ & .019 & .003 & .002 & .013 \\
\hline $\mathrm{Si}$ & I- & 1 & 1 & $I$ \\
\hline AI. & $2-$ & 2 & $2-$ & $2-$ \\
\hline $\mathrm{K}$ & $2-$ & 2 & 2 & $2-$ \\
\hline $\mathrm{Na}$ & 4 & $3+$ & $3+$ & 3 \\
\hline Fe & $3+$ & $2-$ & 2 & $3+$ \\
\hline $\mathrm{Mn}$ & 3 & 4 - & 4 & $4-$ \\
\hline Ca & 1 - & $2+$ & $2-$ & 3 \\
\hline Mg & 3 & $2-$ & 2 & 3 \\
\hline $\mathrm{Ba}$ & 2 & 4 & $4+$ & 4 \\
\hline Sr & 1- & $4+$ & 4 & $5-$ \\
\hline$T i$ & 4 & $3-$ & 3 & 4- \\
\hline $\mathrm{Zr}$ & $5-$ & 4. & 5 & 4- \\
\hline $\mathrm{Cr}$ & $5+$ & $5=$ & 3 & 5 \\
\hline $\mathrm{G} 2$ & 0 & 5 & 6 & 0 \\
\hline $\mathrm{Se}$ & 0 & $5-$ & 5 & 0 \\
\hline$\Psi$ & 0 & 4 & $5-$ & 6 \\
\hline La & 0 & 0 & 0 & 0 \\
\hline $\mathrm{Be}$ & 0 & 0 & 0 & 0 \\
\hline B & 0 & $5-$ & 5- & $5-$ \\
\hline$P$ & 0 & $2-$ & 0 & 0 \\
\hline V & $2-$ & 5 & $4=$ & 5 \\
\hline $\mathrm{Ni}$ & 0 & $6-$ & $3-$ & $4-$ \\
\hline Co & 0 & 0 & 5 & 6 \\
\hline $\mathrm{Cu}$ & $2+$ & $3-$ & $3-$ & $2+$ \\
\hline $\mathrm{Pb}$ & $5+$ & 0 & $5+$ & 4 \\
\hline $\mathrm{Zn}$ & 0 & 0 & 0 & 0 \\
\hline $\mathrm{cd}$ & 0 & 0 & 0 & 0 \\
\hline Mo & 5 & 0 & $5-$ & 0 \\
\hline As & 0 & 0 & 0 & 0 \\
\hline $\mathrm{Ag}$ & 5 & $<6$ ("Tr") & $<6(" \mathrm{Tr} ")$ & 5 \\
\hline$B i$ & 0 & 0 & 0 & 0 \\
\hline$S n$ & 0 & 0 & 0 & 0 \\
\hline
\end{tabular}

I/Samples collected by E. J. McKay (EM-) and E. M. Shoemaker (EMS-).

I Hidden Treasure mine, Klondike Ridge, Colo., sec. 8, T. 43 No, R. 16 W., N.M.P.M. Channel sample. (EM-51-8, D).

2 Vein in Salt Valley, Utah, T。22 S。, R. 20 E., S.I.P.M. Grab sample. (EM-51-13, D).

3 Garnet Ridge, Arizona, lat. $36^{\circ} 56^{\prime}$ No, long. 109 $48^{\prime} \mathrm{W}$. Grab sample; a.ltered rubble dike. (EMS-51-2, D)。

4 Same. Grab sample; copper-stained Navajo sandstone. (EMS-51-1, D). 
44

Table 15A.--Spectrographic ana.lyses of mil1-pu.lp samples of uranium ores, Cortez district, Grants district, House Rock district

\section{Elements}

\begin{tabular}{|c|c|c|c|c|c|}
\hline & $\underline{1}$ & $\underline{2}$ & 3 & $\underline{4}$ & 5 \\
\hline U & 4 & $3=$ & $3-$ & 3 & 3 \\
\hline $\mathrm{U}_{3} \mathrm{O}_{8} \%$ & 0.03 & * & $*$ & 0.14 & 0.26 \\
\hline $\mathrm{eU}_{3} \mathrm{O}_{8} \%$ & 0.031 & * & * & 0.13 & 0.27 \\
\hline $\mathrm{V}_{2} \mathrm{O}_{5} / \mathrm{U}_{3} \mathrm{O}_{8}$ & 6.00 & $*$ & \% & 0.36 & 0.65 \\
\hline Si. & 1 & 2 & 2 & 2 & 1 \\
\hline A.1 & 2 & 2 & 2 & 3 & 3- \\
\hline$K$ & 3 & 0 & 0 & 0 & 0 \\
\hline $\mathrm{Na}$ & 3 & $3=$ & $3=$ & $4+$ & 4 \\
\hline $\mathrm{Fe}$ & 2 & $3+$ & $3+$ & 3 & 0 \\
\hline $\mathrm{Mn}$ & $4+$ & 4 & 4 & $4+$ & 2 \\
\hline $\mathrm{Ca}$ & $2-$ & 1 & 1 & 1 & $3+$ \\
\hline $\mathrm{CaCO}_{3} \%$ & 2.3 & * & $\because$ & 92.8 & 2.5 \\
\hline $\mathrm{Mg}$ & 3 & 3 & 3 & 3 & 4 \\
\hline $\mathrm{Ba}$ & $3-$ & 3 & 3 & 3 & 3 \\
\hline Sr & 4 & $4+$ & $4+$ & $4+$ & 3 \\
\hline Ti & 3 & $4-$ & $4-\infty$ & $4-$ & 5 \\
\hline $\mathrm{Zr}$ & 4. & 5 & $5+$ & 5 & 5 \\
\hline $\mathrm{Cr}$ & $5+$ & $5+$ & 5 & $5-$ & 5 \\
\hline $\mathrm{Ga}$ & 6 & 0 & 0 & 0 & 0 \\
\hline $\mathrm{Sc}$ & $5-$ & 0 & 0 & 0 & 0 \\
\hline$Y$ & 5 & 0 & 0 & 0 & $5+$ \\
\hline La. & 0 & 0 & 0 & 0 & 0 \\
\hline $\mathrm{Be}$ & 6 & 0 & 0 & 0 & 0 \\
\hline B & $5-$ & 0 & 0 & 0 & \\
\hline V & $4+$ & $3+$ & $3+$ & 4 & \\
\hline $\mathrm{V}_{2} \mathrm{O}_{5} \%$ & 0.18 & * & s & 0.05 & 0.17 \\
\hline $\mathrm{Ni}$ & 6 & 0 & To & 6 & 5 \\
\hline Co & $6+$ & 0 & 0 & 6 & 6 \\
\hline $\mathrm{Cu}$ & 5 & 5 & $5-$ & 5. & 4 \\
\hline $\mathrm{Pb}$ & $5-$ & 3 & $3-$ & 5 & 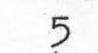 \\
\hline $\mathrm{Zn}$ & 0 & 0 & 0 & 4 & 4 \\
\hline $\mathrm{cd}$ & 0 & 0 & 5 & 0 & 0 \\
\hline Mo & $5-$ & 0 & 0 & $5-$ & 5 \\
\hline $\mathrm{As}$ & 0 & 0 & 0 & 0 & 0 \\
\hline $\mathrm{Ag}$ & $<6\left(" \mathrm{Tr}{ }^{\prime}\right)$ & 0 & 0 & 6 & $5+$ \\
\hline
\end{tabular}

Mines

Cortez district:

1. Veach. (PMS-35-51, D) T。 36 N。, R. 18 W. N.M.P.M.

Grants district:

2 Santa Fe Operation Haystack, Sample no. I of large-scale test sampling, "Uraninite pit"。(GS-92-51, W), sec. 19, T. 13 No, R. 10 W., N.M.P.M.

3 Same. Sample no.2. (GS-93-51, W).

4 Red Point. (PMS -33-5I, D), T. 13 N., R. 10 W., N.M.P.M.

House Rock district:

5 Baker. (PMS-22-51, D)。 District not included in Map of the Uranium Region of the Colorado Plateau. 
Table 15B.--Spectrographic analyses of mill-pulp samples of uranium ores, Gateway district

Elements

\section{Mines}

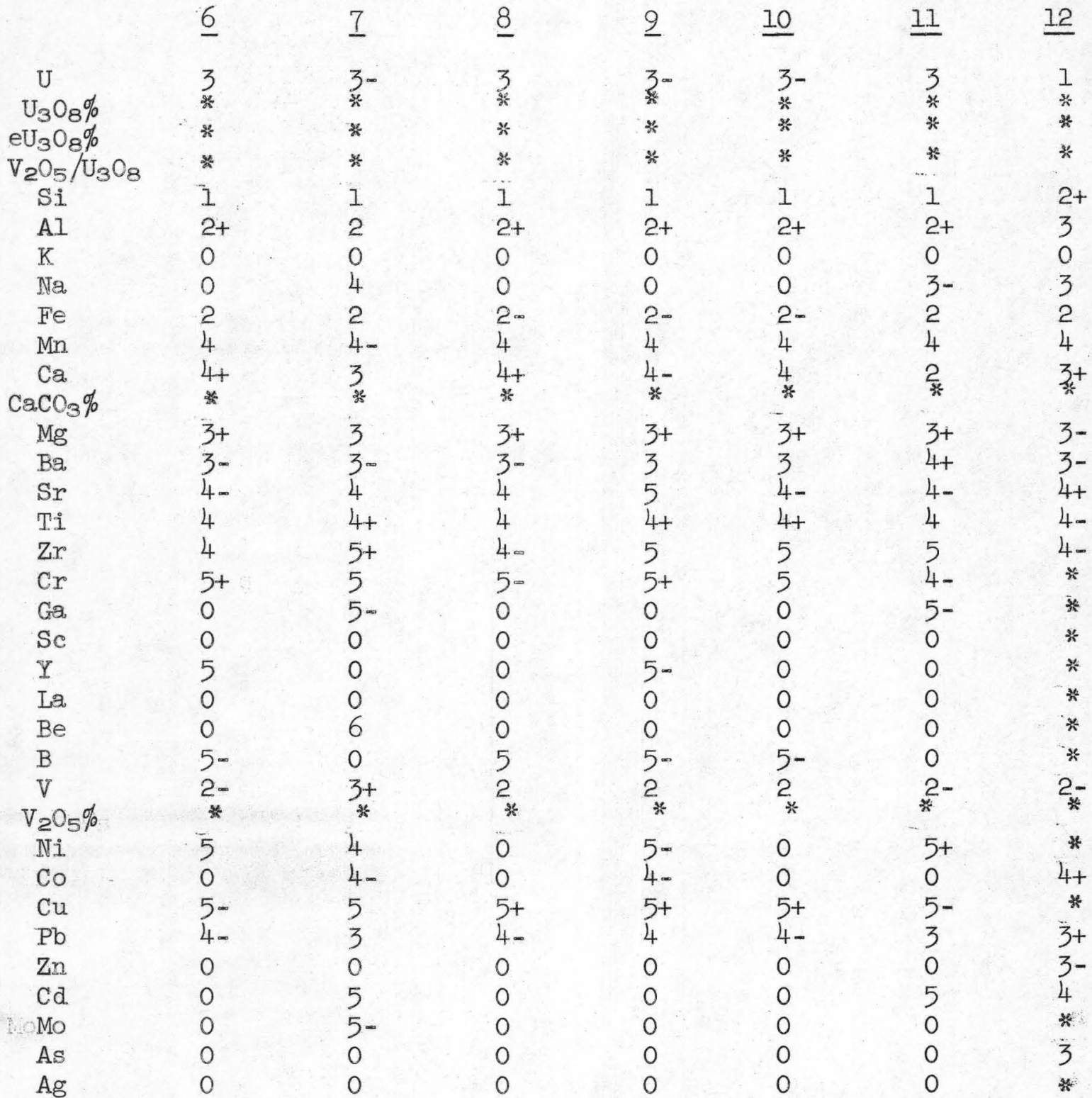

6 Calamity no. 17 (W) sec.11, T. 50 N., R. 18 W., N.M.P.M.

7 Ca.lamity no. 17, low grade, (GS-98-51, W) sec.11, T. 50 N。, R. 18 W. $\mathbb{N} \circ M \circ P \circ M$ 。

8 Ca.lamity no. 13 (GS $-42-50$, W) sec。11, T. 50 N., R. 18 W., N.M.P.M.

9 Calamity no. 27 (GS-40-50, W) sec。11, T. 50 N., R. 18 W., N.M.P.M.

10 Calamity no. 21 (GS-4l-50, W) sec。11, T。 50 N., R. 18 W., N.M.P.M.

11. Matchless (GS $-99-51, W)$ sec.9, T. 50 N。, R. 18 W. N.M.P.M.

12 La Sa.I no. 2, high grade, (GS-108-51, W) sec. 34, T. 51 N., R. 20 W., $N . M . P . M 。$ 
46

Table 15C.--Spectrographic analyses of mill-pulp samples of uranium ores, Gypsum Valley and Southern Bull Canyon districts

Eilements

Mines

\begin{tabular}{|c|c|c|c|c|c|c|}
\hline & 13 & 14 & 15 & & 16 & 17 \\
\hline $\mathrm{U}$ & 3 & 3 & 3 & & 3. & 3 \\
\hline $\mathrm{U}_{3} \mathrm{O}_{8} \%$ & 0.16 & 0.32 & 0.14 & & * & 0.12 \\
\hline $\mathrm{eU}_{3} \mathrm{O}_{8} \%$ & 0.18 & 0.27 & 0.12 & & $\%$ & 0.15 \\
\hline $\mathrm{V}_{2} \mathrm{O}_{5} / \mathrm{U}_{3} \mathrm{O}_{8}$ & 4.69 & 9.62 & 11.45 & & * & 19.17 \\
\hline Si & 1 & $2+$ & $2+$ & & 1 & 1. \\
\hline A.1. & $2 \infty$ & $3+$ & $2-$ & & $2+$ & 2 \\
\hline $\mathrm{K}$ & 2 & 2 & 2 & & 0 & $3+$ \\
\hline $\mathbb{N a}$ & $4+$ & $3-$ & $3-$ & & $4+$ & $3-$ \\
\hline $\mathrm{Fe}$ & 3 & $2-$ & $2 \infty$ & & 2 & $2-$ \\
\hline $\mathrm{Mn}$ & 4 & $3=$ & $3=$ & & 4 & 4 \\
\hline $\mathrm{Ca}$ & 2 & 2 & 2 & & 2 & 2 \\
\hline $\mathrm{CaCO}_{3} \%$ & 9.4 & 29.3 & 30.6 & & $*$ & 2.9 \\
\hline $\mathrm{Mg}$ & 2 & 2 & 2 & & $3+$ & $3+$ \\
\hline $\mathrm{Ba}$ & $4+$ & 4 & 4 & & 4 & 3 \\
\hline Sr & $5+$ & 4 & 4 & & 4 & 4 \\
\hline Ti & $4+$ & $4+$ & $4+$ & & $4+$ & 3 \\
\hline Zr & 4 & 4 & $4-$ & & $5+$ & 4 \\
\hline $\mathrm{Cr}$ & $5=$ & 5 & 5 & & 5 & 5 \\
\hline $\mathrm{Ga}$ & 6 & 6 & 6 & & 5. & 6 \\
\hline $\mathrm{Sc}$ & 0 & 0 & 0 & $=$ & 0 & $5-$ \\
\hline$Y$ & 6 & 6 & 50 & & 0 & 5 \\
\hline Ia & 0 & 0 & 0 & & 0 & 0 \\
\hline $\mathrm{Be}$ & 0 & 0 & 0 & & 0 & 0 \\
\hline B & 5 & $5+$ & $5+$ & & 0 & 5 \\
\hline V & 3 & 2 & 2 & & 2. & 2 \\
\hline $\mathrm{V}_{2} \mathrm{O}_{5} \%$ & 0.77 & 3.08 & 2.65 & & * & 2.38 \\
\hline $\mathrm{N} 1$ & 6 & 5 & 5 & & 4. & 6 \\
\hline Co & 6 & 6 & 6 & & 4. & 6 \\
\hline $\mathrm{Cu}$ & 5 & 5 & 5 & & 4 & 4 \\
\hline $\mathrm{Pb}$ & 5 & 5 & 5 & & 3 & 5 \\
\hline $\mathrm{Zn}$ & 4 & 4 & 4 & & 0 & 4 \\
\hline cd. & $*$ & $*$ & 然 & & 4. & $*$ \\
\hline Mo & $5-$ & $5-$ & $5-$ & & 4. & 5 \\
\hline $\mathrm{As}$ & 0. & 0 & 0 & & 0 & 0 \\
\hline $\mathrm{Ag}$ & $\angle 6\left(" \operatorname{Tr}^{n}\right)$ & 0 & 0 & & 6 & $6+$ \\
\hline
\end{tabular}

Gypsum Valley district:

13 Pitchfork (PMS $-8-51$, D), sec.33, T. 44 N., R. 16 W., N.M.P.M.

14 Bald Eagłe, high grade, (PMS -45-51, D), sec.29, T. 44 N., R. 16 W., N.M.P.M.

15 Bald Eage, low grade, (PMS $-44-51, D)$, sec. 29, T. 44 N., R. 16 W., N.M.P.M.

16 Terrible (GS-107-51, W), sec. 10, T. 45 N., R。 19 W., N.M.P.M。 Southern Bull Canyon district:

17 Lookout (PMS $-4-51, \mathrm{D}$ ), sec。36, T. 45 N., R. 18 W., N.M.P.M. 
Table 15D,--Spectrographic analyses of mill-pulp samples of uranium ores, Henry Mountains district

Elements

Mines

\begin{tabular}{|c|c|c|c|c|c|c|}
\hline & 18 & 19 & 20 & 21 & 22 & 23 \\
\hline U & 3 & 3 & 3 & 3 & 3 & 3 \\
\hline $\mathrm{U}_{3} \mathrm{O}_{8} \%$ & 1.12 & 0.84 & 0.65 & 0.14 & 0.16 & 0.12 \\
\hline $\mathrm{eU}_{3} \mathrm{O}_{8} \%$ & 1.0 & 0.78 & 0.51 & 0.32 & 0.14 & 0.12 \\
\hline $\mathrm{V}_{2} \mathrm{O}_{5} / \mathrm{U}_{3} \mathrm{O}_{8}$ & 1.88 & 3.83 & 3.62 & 0.36 & 6.81 & 7.58 \\
\hline SI & 1 & 1 & 1 & 1 & 1 & 1 \\
\hline A.1 & 2 & $2-$ & 2 & 2- & 2 & 2 \\
\hline $\mathrm{K}$ & 2 & $2=$ & $3+$ & 2 & 2 & 2 \\
\hline $\mathrm{Na}$ & 30 & $3 \infty$ & $3=$ & 3 & $3+$ & 3 \\
\hline $\mathrm{Fe}$ & $2 \infty$ & 2 & 2 & 2 & 2 & 2 \\
\hline $\mathrm{Mn}$ & 4 & 4 & 4 & 5 & 4 & 4 \\
\hline $\mathrm{Ca}$ & $2-$ & 3 & 2 & 2 & 2 & 2 \\
\hline $\mathrm{CaCO}_{3} \%$ & 4.1 & 3.1 & 4.3 & 8.4 & 6.3 & 4.0 \\
\hline $\mathrm{Mg}$ & 3 & 3 & 3 & 3 & $3+$ & 3 \\
\hline $\mathrm{Ba}$ & 4 & 3 & $3 \infty$ & 3 & $3-$ & $4+$ \\
\hline Sr & 5 & 4 & 4 & 4 & 4 & 4 \\
\hline$T: 2$ & 4 & $4+$ & $4+$ & $4+$ & 3 & 3 \\
\hline Zro & 4 & 4 & 4 & 4 & 4 & 4 \\
\hline $\mathrm{Cr}$ & 5- & $5^{\circ}$ & 5 & 5 & 5 & 5 \\
\hline $\mathrm{Ga}$ & 6 & 6 & 6 & 5 & 6 & 6 \\
\hline $\mathrm{Sc}$ & 50 & 0 & $5=$ & $5=$ & $5-$ & 5 \\
\hline$Y$ & 5 & 5 & 5 & 5 & $5+$ & $5+$ \\
\hline Ia & 0 & 0 & 0 & 5 & 5 & 5 \\
\hline $\mathrm{Be}$ & 6 & 6 & 6 & 0 & 6 & 6 \\
\hline B & 5 & $5-$ & 5 & $5-$ & 5 & 5 \\
\hline V & $2 \infty$ & 2 & 2 & $5+$ & $3+$ & 3 \\
\hline $\mathrm{V}_{2} \mathrm{O}_{5} \%$ & 2.10 & 3.23 & 2.39 & 0.05 & 1.09 & 0.91 \\
\hline $\mathrm{N} 1$ & 5 & 5 & 5 & 5 & $5+$ & 5 \\
\hline $\mathrm{CO}$ & 5 & $5+$ & 5 & 5 & $5+$ & 5 \\
\hline Cu. & 5 & 5 & 5 & 5. & 5 & 5 \\
\hline $\mathrm{Pb}$ & 4 & 5 & 5 & 4 & 5 & 5 \\
\hline $\mathrm{Zn}$ & 4 & 4. & 4 & 3 & 0 & 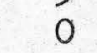 \\
\hline $\mathrm{Cd}$ & $\%$ & $\%$ & $\%$ & * & * & * \\
\hline Mo & 5 & 4 & 4 & 4 & $4-$ & \\
\hline $\mathrm{As}$ & 0 & 4 & 4. & 4 & 0 & \\
\hline $\mathrm{Ag}$ & $<6\left({ }^{n} \operatorname{Tr}{ }^{n}\right)$ & 0 & $<6$ ("Tr") & 0 & 6 & \\
\hline
\end{tabular}

18 Lucky Strike (PMS-27-51, D) T。 35 S。, R。 II E。, S.I.P.M。 (not surveyed.).

19 Taylor Ridge (PMS $-55-51, D)$ T. 33 S。, R。 I2 E., S.L.P.M. (survey not shown on map).

20 Congress group (PMS-2-51, D) T. 31 S。, R. 11 and 12 E。, S.I.P.M. (survey not shown on map).

21. Poison Springs no. 2 (PMS $-30-51$, D) T. 31 S。, R. 13 E., S.L.P.M. (not surveyed).

22 Rattler no. 1 (PMS-31-5I, D) T. 29 S。R. II E., S.L.P.M.

23 Hard Scrabble no. I (PMS-25-5I, D) T. $33 \mathrm{~S}$, , R。 12 E., S.L.P.M. (survey not shown on map; location uncertain). 
Table 15E.--Spectrographic ana.lyses of mill-pulp samples of uranium ores, Moab district

Elements

Mines

\begin{tabular}{|c|c|c|c|c|c|}
\hline & 24 & 25 & 26 & 27 & 28 \\
\hline U & 4 & 3 & 3 & 3 & 8 \\
\hline $\mathrm{U}_{3} \mathrm{O}_{8} \%$ & 0.03 & 0.35 & 0.12 & 0.21 & 0.14 \\
\hline $\mathrm{eU}_{3} \mathrm{O}_{8} \%$ & 0.032 & 0.34 & 0.12 & 0.19 & 0.12 \\
\hline $\mathrm{V}_{2} \mathrm{O}_{5} / \mathrm{U}_{3} \mathrm{O}_{8}$ & 10.0 & 3.32 & 6.73 & 8.24 & 7.14 \\
\hline $\mathrm{Si}$ & 1 & $I^{\prime}$ & 1 & 1 & 1 \\
\hline Al & 2 & $2-$ & 2 & 2 & 2 \\
\hline $\mathrm{K}$ & 2 & $3+$ & 3 & 2 & 2 \\
\hline $\mathrm{Na}$ & 3 & 4 & 4 & $3-$ & $4+$ \\
\hline $\mathrm{Fe}$ & $3+$ & $3+$ & $3+$ & $3+$ & $2-$ \\
\hline $\mathrm{Mn}$ & 5 & 4. & 4 & 4 & 4 \\
\hline $\mathrm{Ca}$ & 3 & $3+$ & 2. & 2 & $2-$ \\
\hline $\mathrm{CaCO}_{3} \%$ & $2 . \overline{4}$ & 2.1 & 4.0 & 9.6 & 2.6 \\
\hline $\mathrm{Mg}$ & 3 & 3 & 3 & 3 & 3 \\
\hline $\mathrm{Ba}$ & $3-$ & 3 & 3 & 3 & 3 \\
\hline $\mathrm{Sr}$ & $5+$ & $4-$ & $4=$ & 4 & 4 \\
\hline T⿺ & $4+$ & $4 t$ & $4+$ & 3 & 3 \\
\hline Zr & 4 & 4 & 4 & $3-$ & 4 \\
\hline $\mathrm{Cr}$ & 5 & 50 & $5-$ & 5 & 5 \\
\hline $\mathrm{Ga}$ & 6 & 6 & 6 & 6 & 6 \\
\hline $\mathrm{Sc}$ & 5- & $5-$ & 0 & $5-$ & 0 \\
\hline$Y$ & $5-$ & 5 & 5 & 5 & 5 \\
\hline La & 0 & 0 & 0 & 0 & 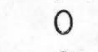 \\
\hline $\mathrm{Be}$ & 0 & 0 & 0 & 0 & 0 \\
\hline B & 5- & $5-$ & $5=$ & 5 & \\
\hline V & 3 & $3+$ & $3+$ & 2 & $3+$ \\
\hline $\mathrm{V}_{2} \mathrm{O}_{5} \%$ & 0.30 & 1.15 & 0.81. & 1.73 & 1.00 \\
\hline $\mathrm{NI}$ & 6 & $5-$ & 5 & 5 & 5 \\
\hline $\mathrm{CO}$ & 5 & 5 & 5 & 5 & 5 \\
\hline $\mathrm{Cu}$ & 4 & 4 & 4 & 5 & \\
\hline $\mathrm{Pb}$ & $4+$ & 4 & 4- & 4 & $4+$ \\
\hline $\mathrm{Zn}$ & 4 & 4 & 4 & 4 & 3- \\
\hline $\mathrm{cd}$ & * & H & $\%$ & $*$ & \\
\hline Mo & 5 & 5 & 5 & $5-$ & \\
\hline As & 0 & 4 & 0 & 0 & 4 \\
\hline $\mathrm{Ag}$ & 5 & $6+$ & $5-$ & $6+$ & \\
\hline
\end{tabular}

24 A. Rogers (PMS-21-51, D) sec.2, T. 27 S., R. 23 E., S.L.P.M.

25 Yellow Circle A, high grade, (PMS-51-5I, D) sec.3, T.28 S., R. 23 E., S.L.P.M.

26 Yellow Circle A, low grade, (PMS-50-51, D) sec. 3, T. 28 S., R. 23 E., S.L.P.M.

27 Top (PMS-34-5I, D) sec. 3I, T. 27 S., R. 23 E., S.L.P.M.

28 Redlands (PMS $-32-51$, D) sec. 35, T. 27 S., R. 22 E., S.L.P.M. 
Table 15F--mpectrographic analyses of mill-pulp samples of uranium oxes, Monticello district (northern half)

E.lements

Mines

\begin{tabular}{|c|c|c|c|c|c|c|c|}
\hline & 39 & 30 & 31 & 32 & 33 & 34 & 35 \\
\hline U & 4 & 3 & 3 & 3 & 3 & 3 & 3 \\
\hline $\mathrm{U}_{8} \mathrm{O}_{8} \%$ & 0.07 & 0.21 & 0.18 & 0.17 & 0.099 & 0.13 & 0.16 \\
\hline $\mathrm{ev}_{3} \mathrm{O}_{\mathrm{g}} \%$ & 0.065 & 0.21 & 0.18 & 0.14 & 0.093 & 0.14 & 0.11 \\
\hline $\mathrm{V}_{2} \mathrm{O}_{5} / \mathrm{U}_{3} \mathrm{O}_{8}$ & 30.0 & 6.7 & 5.4 & 5.9 & 8.6 & 7.5 & 2.1 \\
\hline si & 1 & 1 & 1 & 1 & 1 & 1 & 1 \\
\hline A.I. & 2 & 2 & 2- & $2-$ & 2. & $2-$ & 2. \\
\hline $\mathrm{K}$ & 3 & 3 & 3 & 0 & 0 & 0 & $3+$ \\
\hline Na & 3 & 3 & $3=$ & $3-$ & $4+$ & $4+$ & 3 \\
\hline $\mathrm{Fe}$ & 2. & $3+$ & 3 & $3+$ & $3+$ & $3+$ & 3 \\
\hline $\mathrm{Mn}$ & 4 & 4 & 4 & 4 & 4 & 4 & 3 \\
\hline $\mathrm{Ca}$ & 2 & $3+$ & 3 & 2 & 2. & 2. & 2 \\
\hline $\mathrm{CaCO}_{3} \%$ & 5.2 & 3.0 & 2.7 & $5.7=$ & 4.8 & 4.3 & 4.3 \\
\hline $\mathrm{Mg}$ & 3 & $3+$ & 3 & 3 & 3 & 3 & $3+$ \\
\hline B\& & 3 & $4+$ & $4+$ & 4 & 4 & $4+$ & $3-$ \\
\hline sx & 4 & $5+$ & 5 & $5+$ & 5 & 5 & 4 \\
\hline Ti: & $4 t$ & $3 \infty$ & 4 & $4+$ & 4 & 4 & $4+$ \\
\hline $\mathrm{Zr}$ & $4+$ & 4 & 4 & 4 & 4 & 4 & 5 \\
\hline $\mathrm{Cr}$ & 5. & $5=$ & 6 & $5-$ & 6 & $5-$ & 5 \\
\hline Ga & 6 & 0 & 6 & 0 & 0 & 0 & 6 \\
\hline Se & $5-$ & 0 & $5-$ & 0 & 0 & 0 & $5-$ \\
\hline$\Psi$ & 5 & 5 & 5 & 5 & 5 & 5- & $5+$ \\
\hline L2 & 0 & 0 & 0 & 0 & 0 & 0 & $5+$ \\
\hline $\mathrm{Be}$ & 0 & 0 & 0 & 0 & 0 & 0 & 6 \\
\hline B & $5=$ & 5 & 5 & 5- & $5-$ & 5- & 5 \\
\hline V & $2 \infty$ & 2 & 3 & $3+$ & 3 & 3 & $3-$ \\
\hline $\mathrm{V}_{2} \mathrm{O}_{5} \%$ & 2.10 & 1.38 & 1.00 & 0.99 & 0.85 & 1.00 & 0.34 \\
\hline $\mathrm{N} i$ & 6 & 6 & 6 & 6 & 6 & 6 & 6 \\
\hline $\mathrm{Co}$ & 6 & 5 & 6 & 6 & 6 & 6 & 6 \\
\hline $\mathrm{Cu}$ & 5 & $5+$ & 5 & 5 & 5 & 5 & 5 \\
\hline $\mathrm{Pb}$ & 5 & 5 & 5 & 5 & 6 & 5 & 5 \\
\hline $\mathrm{Zn}$ & 4 & 4 & 4 & 4 & 4 & 5 & 4 \\
\hline $\mathrm{cd}$ & \% & $\%$ & $\%$ & * & * & * & $*$ \\
\hline Mo & 0 & 6 & 6 & 5 & 5- & $6+$ & 5 \\
\hline As & 0 & 0 & 0 & 0 & 0 & 0 & 0 \\
\hline $\mathrm{Ag}$ & 6 & 6 & 6 & 6 & $\angle \sigma(" \nabla r ")$ & 6 & $\angle 6\left(^{\prime \prime}\right.$ \\
\hline
\end{tabular}

29 Pinch (PMS-29-51, D) sec。19, T. 31. S。, R. 25 E., S.I.P.M.

30. Bee (PMS-41-51, D) sec。8, T. 31. S。, R。25 E。, S.L.P.M.

31 Genevs (PMS-16-51, D) sec。 I, T. 31 S., R. 24 E., S.L.P.M.

32 Dime (PMS $-9.51, D)$ sees, 6 and 7, T. 31 S., R. 25 E。, S.L.P.M.

33 Waterfa11 (PMS-14-51, D) secs. 6 and 7, T。 31 S.g. 25 E., S.I.P.M.

34. Wilson (PMS-13-51, D) sec. 36, T. 30 S。, R。 24 E。, S.L.P.M.

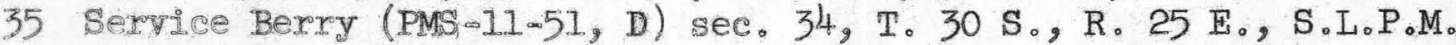


Table 15F.--Continued

\section{Elements}

\section{Mines}

\begin{tabular}{|c|c|c|c|c|}
\hline & $\underline{36}$ & 37 & $\underline{38}$ & 39 \\
\hline $\mathrm{U}$ & 3 & 3 & 4 & 4 \\
\hline $\mathrm{U}_{3} \mathrm{O}_{8} \%$ & 0.28 & 0.12 & 0.06 & 0.06 \\
\hline $\mathrm{eU}_{3} \mathrm{O}_{8} \%$ & 0.35 & 0.11 & 0.056 & 0.070 \\
\hline $\mathrm{V}_{2} \mathrm{O}_{5} / \mathrm{U}_{3} \mathrm{O}_{8}$ & 1.58 & 8.93 & 16.16 & 27.0 \\
\hline $\mathrm{Si}$ & 1 & 1 & 1 & 1 \\
\hline $\mathrm{Al}$ & 2 & $2-$ & 2 & 2 \\
\hline $\mathrm{K}$ & $2-$ & $3+$ & 0 & 3 \\
\hline $\mathrm{Na}$ & 3 & $3-$ & $3-$ & 3 \\
\hline $\mathrm{Fe}$ & $2-$ & $3+$ & $2-$ & $2-$ \\
\hline Mn & 4 & 4. & 4 & 4 \\
\hline $\mathrm{Ca}$ & 2 & $2-$ & 2 & 2 \\
\hline $\mathrm{CaCO}_{3} \%$ & 18.4 & 13.7 & 13.3 & 15.5 \\
\hline $\mathrm{Mg}$ & 3 & 3 & 3 & $3+$ \\
\hline $\mathrm{Ba}$ & 3 & 3 & $4+$ & 3 \\
\hline $\mathrm{Sr}$ & 4 & 4 & 4 & 4 \\
\hline $\mathrm{Ti}$ & $4+$ & $3-$ & 4 & 4 \\
\hline $\mathrm{Zr}$ & 5 & 4 & 4 & 4 \\
\hline $\mathrm{Cr}$ & $5-$ & $5=$ & $5-$ & 5 \\
\hline $\mathrm{Ga}$ & 6 & 6 & 0 & 6 \\
\hline $\mathrm{Sc}$ & 0 & 0 & 0 & $5-$ \\
\hline$Y$ & $5+$ & 5 & 5 & 5 \\
\hline $\mathrm{La}$ & 0 & 0 & 0 & 0 \\
\hline $\mathrm{Be}$ & 6 & 0 & 0 & 0 \\
\hline B & $5-$ & $5-$ & $5-$ & $5-$ \\
\hline V & 3 & $3+$ & $3+$ & $3+$ \\
\hline $\mathrm{V}_{2} \mathrm{O}_{5} \%$ & 0.45 & 1.03 & 0.97 & 1.62 \\
\hline $\mathrm{Ni}$ & 5 & 6 & 6 & 5 \\
\hline Co & 5 & $6+$ & 6 & 5 \\
\hline $\mathrm{Cu}$ & 5 & 5 & 5 & 5 \\
\hline $\mathrm{Pb}$ & 5 & 5 & 5 & 4 \\
\hline $\mathrm{Zn}$ & 0 & 4 & 4 & 4 \\
\hline $\mathrm{cd}$ & * & * & * & * \\
\hline Mo & 4 & 6 & $5+$ & $4-$ \\
\hline As & 0 & 0 & 0 & 0 \\
\hline $\mathrm{Ag}$ & $<6(" \mathrm{Tr} ")$ & 0 & 6 & $6+$ \\
\hline
\end{tabular}

36 Hole in the Rock (PMS-6-51, D) sec。10, T。 40 S。, R。22 E., S.L.P.M.

37 Gold Butte no. I (PMS-36-5I, D) sec. 4, T. 38 S., R. 21 E., S.L.P.M.

38 Hoot Owl (PMS-26-5I, D) sec. 3, T. 37 S., R。24 E., S.L.P.M.

39 Cloudy Day (PMS-23-5I, D) sec。34, T. 36 S., R. 24 E., S.L.P.M. 
Table 15G.--Spectrographic analyses of mill-pulp samples of uranium ores, Monument Valley district

Elements

Mines

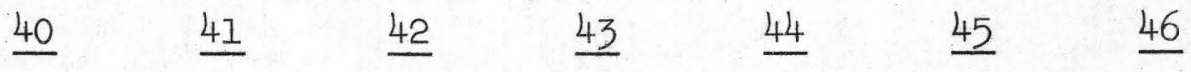

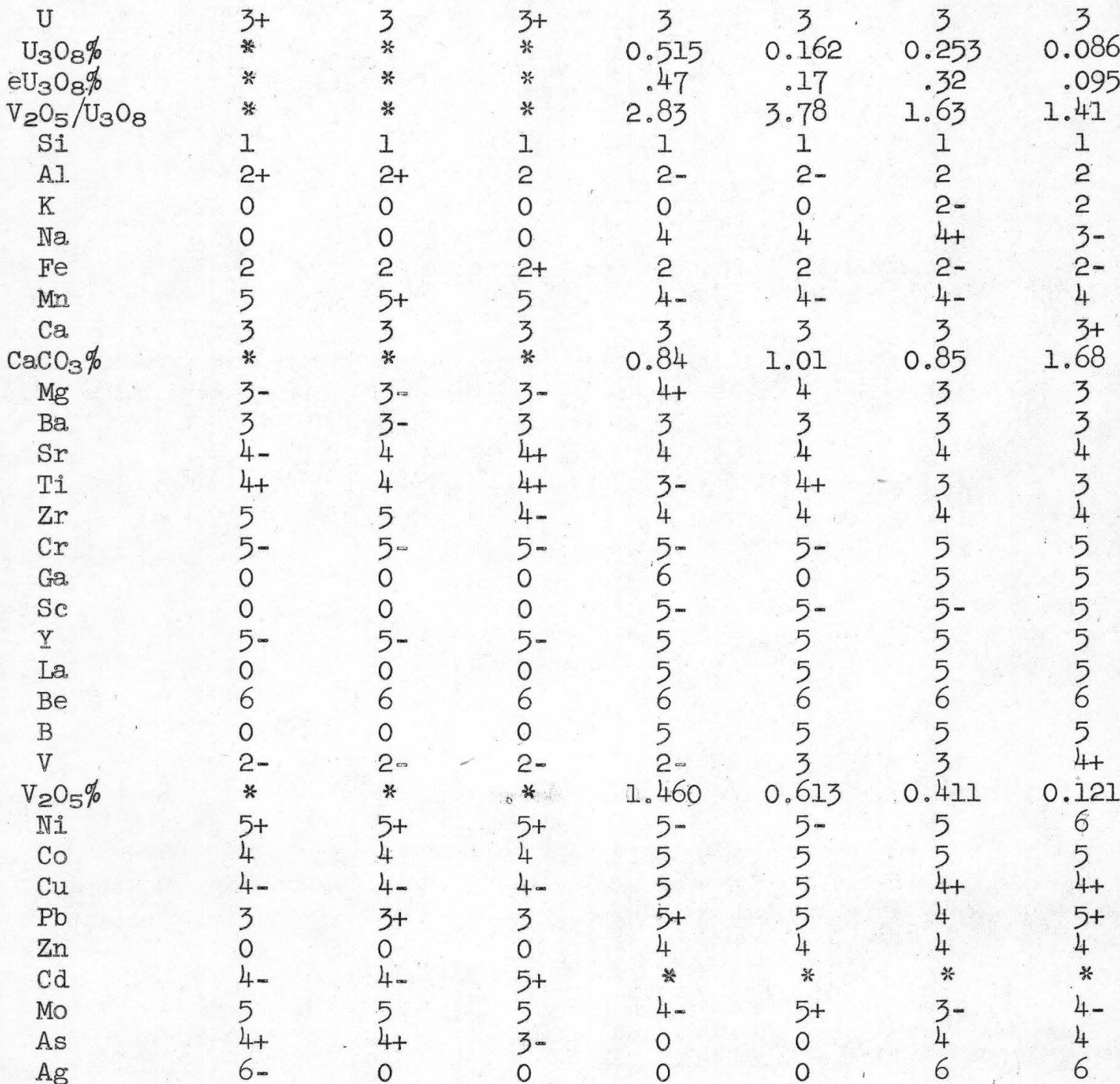

40 Monument no. 2, high grade, (GS $-84-51$, W) lat. $36^{\circ} 56^{\prime} \mathrm{N} .$, long. $109^{\circ} 53^{\prime} \mathrm{W}$.

41 Monument no. 2, intermediate grade, (GS-83-51, W) lat. $36^{\circ} 56^{\prime} \mathrm{N}$. , long. $109^{\circ} 53^{\circ} \mathrm{W}$.

42 Monument no. 2, low grade, (GS-82-51, W) lat. $36^{\circ} 56^{\prime} \mathrm{N} .$, long: $109^{\circ} 53^{\prime} \mathrm{W}$.

43 Cato Sells, high grade, (PMS-53-51, D) lat. $36^{\circ} 56^{\prime}$ N., long. $109^{\circ} 53^{\prime} \mathrm{W}$.

44 Cato Sells, Iow grade, (PMS-52-51, D) lat. $36^{\circ} 56^{\prime} \mathrm{N}$, long. $109^{\circ} 53^{\prime} \mathrm{W}$.

45 Skyline, high grade, (PMS -38-51, D) lat. $37^{\circ} 01^{\prime} \mathrm{N}$, long. $110^{\circ} 13^{\prime} \mathrm{W}$.

46 Skyline, low grade, (PMS-37-51, D) lat. $37^{\circ} \mathrm{OI}$ ' N., long. $110^{\circ} 13^{\prime} \mathrm{W}$. 
Table 15H.--Spectrographic analyses of mill-pulp samples of uranium ores, Paradox district

Elements

Mines

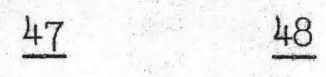

49

50

51

$\mathrm{U}$

$\mathrm{U}_{3} \mathrm{O}_{8} \%$

3
0.18

$\mathrm{eU}_{3} \mathrm{O}_{8} \%$

0.18

$\mathrm{V}_{2} \mathrm{O}_{5} / \mathrm{U}_{3} \mathrm{O}_{8}$

2.64

$\mathrm{Si}$

A.

$\mathrm{K}$

Na.

$\mathrm{Fe}$

$\mathrm{Mn}$

$\mathrm{Ca}$

$\mathrm{CaCO}_{3} \%$

1

2-

$2-$

4

$3+$

2-

$\mathrm{Mg}$

3.15

$\mathrm{Ba}$

$\mathrm{Sr}$

Ti

$\mathrm{Zr}$

Cr

Ga

Sc

$Y$

La

Be

B

$\mathrm{V}$

$\mathrm{V}_{2} \mathrm{O}_{5} \%$

$\mathrm{Ni}$

Co

$\mathrm{Cu}$

$\mathrm{Pb}$

Zn

ca

Mo

As

$\mathrm{Ag}$

0

5-

5

0

0

5

3

0.49

$6+$

5
4

4

$4+$

*

5

0

6
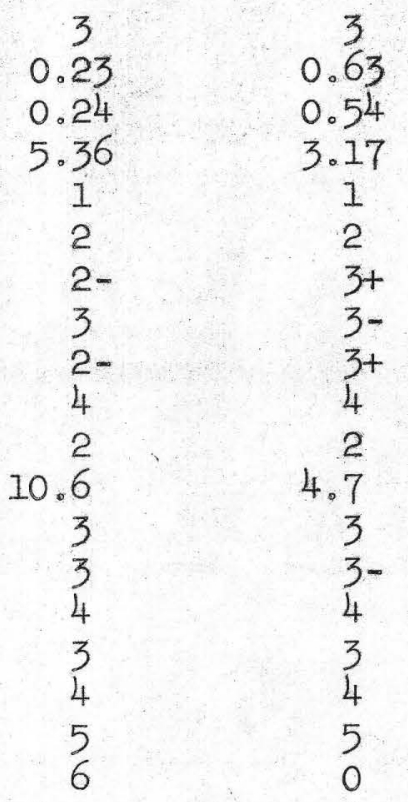

0.46

0.51

*

0.54

3.17

4.09

1

2

0

$3-$

2-

$4-$

4

*

$3+$

3

4

4 -

$4+$

0

0

$5-$

0

5

5

5

$4+$

3

0

0

0

0

1

1

2-

$3+$

2

4.7

3
1.4

3

$3-$

3
4

44

3

3

$5+$

4

4

5

0

5-

5

0

0

5

55

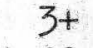

1.22

2-

1.90

6

6

6

5

5

5

4

4

*

*

6

5

$<6$ ("Tr") $\quad<6(" \operatorname{Tr} ")$

0

5

47 Rajah (PMS -40-51, D) sec. 12, T. 48 N., R. 19 W., N.M.P.M.

48 Red Bird (GS-49-50, W) sec. 9, T. 48 N., R. 19 W., N.M.P.M.

49 Radium Cycle (PMS-3-51, D) sec. 8, T. 48 N., R. 19 W., N.M.P.M.

50 Valley View (PMS -5-51, D) sec. 7, T. 48 N., R. 19 W., N.M.P.M.

51 Grey Dawn (PMS-17-51, D) sec. 30, T. 28 S。, R。 26 E., S.L.P.M. 
Table 15I.--Spectrographic analyses of mill-pulp samples of uranium ores, San Rafael and western Green River districts

Elements

\section{Mines}

\begin{tabular}{|c|c|c|c|c|c|c|c|}
\hline & 52 & 53 & 54 & 55 & $\underline{56}$ & 57 & $\underline{58}$ \\
\hline$\underset{U_{3} \mathrm{O}_{0} \%}{\mathrm{U}}$ & 3- & $3-$ & 3 & 3- & 3 & 3 & 0,30 \\
\hline $\begin{array}{l}\mathrm{eU}_{3} \mathrm{U}_{8} \% \\
\end{array}$ & * & * & * & * & $\begin{array}{l}0.14 \\
0.13\end{array}$ & $\begin{array}{l}0.17 \\
0.16\end{array}$ & $\begin{array}{l}0.30 \\
0.30\end{array}$ \\
\hline $\mathrm{V}_{2} \mathrm{O}_{5} / \mathrm{U}_{3} \mathrm{O}_{8}$ & * & * & * & * & 0.61 & 0.55 & 3.6 \\
\hline $\mathrm{Si}$ & 1 & 1 & 1 & 1 & 1 & 1. & 1 \\
\hline Al & 2 & 2 & 2 & 1 & $2-$ & 2 & \\
\hline $\mathrm{K}$ & 0 & 0 & 0 & 0 & 3 & $3+$ & \\
\hline $\mathrm{Na}$ & 0 & 0 & 0 & 0 & 4 & $4+$ & \\
\hline $\mathrm{Fe}$ & 2 & 2 & 2 & 2 & $2-$ & $2-$ & \\
\hline Mn & 4 & $4-$ & 4 & 4- & 4 & 4 & \\
\hline $\mathrm{Ca}$ & 3 & 3 & $3+$ & $3+$ & $2-$ & 2 & \\
\hline $\mathrm{CaCO}_{3} \%$ & 5 & * & * & * & 3.3 & 6.4 & 1.7 \\
\hline $\mathrm{Mg}$ & 3 & 3 & $3-$ & 3- & 3 & $3+$ & \\
\hline $\mathrm{Ba}$ & 4 & 4 & $4+$ & $4+$ & $3+$ & $4+$ & \\
\hline $\mathbf{S x}$ & $4-$ & 4- & 4 & 4 & 4 & $5+$ & \\
\hline Ti & 4 & 4 & $4+$ & 3 & 3 & 3 & \\
\hline $\mathrm{Zr}$ & 4- & $5+$ & $4-$ & $4-$ & 5 & 4 & \\
\hline $\mathrm{Cr}$ & 4- & 5 & $4-$ & $3-$ & 5. & 5 & \\
\hline $\mathrm{Ga}$ & 0 & 0 & 0 & 0 & 6 & 6 & \\
\hline Sc & 0 & 0 & 0 & 6 & 5- & 5 & \\
\hline$Y$ & 0 & 0 & $5-$ & 5 & 5 & 5 & \\
\hline La & 0 & 0 & 0 & 0 & 0 & 0 & \\
\hline $\mathrm{Be}$ & 0 & 0 & 0 & 6 & 6 & 6 & \\
\hline B & 0 & 0 & 0 & 0 & 5- & 5 & \\
\hline V & $3+$ & $3+$ & 3 & $3+$ & 4 & 4 & \\
\hline $\mathrm{V}_{2} \mathrm{O}_{5} \%$ & * & * & * & * & 0.09 & 0.09 & 1.0 \\
\hline $\mathrm{N} i$ & $5+$ & 5 & 4- & 4 & 5 & 4 & \\
\hline Co & 0 & 5 & 4 & 4 & 5 & 4 & \\
\hline $\mathrm{Cu}$ & 5 & $5-$ & $5+$ & $5+$ & 4 & 4 & \\
\hline $\mathrm{Pb}$ & $4+$ & $4+$ & $3-$ & 3 & $4+$ & 4 & 5 \\
\hline $\mathrm{Zn}$ & 0 & 0 & 0 & $4-$ & 3 & 3 & \\
\hline $\mathrm{Cd}$ & 0 & 0 & 0 & 0 & * & * & \\
\hline Mo & 5 & 5- & 5 & $5-$ & 4 & 5 & \\
\hline As & 0 & 0 & 0 & $4+$ & 0 & 0 & \\
\hline $\mathrm{Ag}$ & 0 & 0 & 0 & 0 & 6 & $<6(" \operatorname{Tr} ")$ & \\
\hline
\end{tabular}

San Rafael district: (not surveyed)

52 Vanadium King no. 2 (GS-91-5I, W) sec. 26, T. 24 S., R。 11 E., S.I.P.M. 53 Camp Bird no. 12 S。 (GS-90-51, W) sec. 35, T. 24 S., R. 11 E., S.L.P.M. 54 Camp Bird no. $12 \mathrm{~N}$. (GS-89-51, W) sec. 35, T. 24 S., R. 11 E., S.I.P.M. 55 Camp Bird no. 13 (GS-88-51, W) sec. 35, T. 24 S., R. 11 E., S.L.P.M. 56. Dirty Devil nos. 3, 4 (PMS-10-5I, D) sec. 35, T. 24 S., R. 8 E., S.I.P.M.

57 Lucky Strike no. 2 (PMS-7-5I, D) sec. 6, T. 24 S., R. 9 E., S.L.P.M. Western Green River district: 58 Wedding Bell (PMS-15-51, D) sec。22, T. 21 S., R. 14 E., S.L.P.M. 
54

Table 15J.--Spectrographic ana.lyses of mill-pulp samples of uranium, ores, Shiprock distriet

\section{Elements}

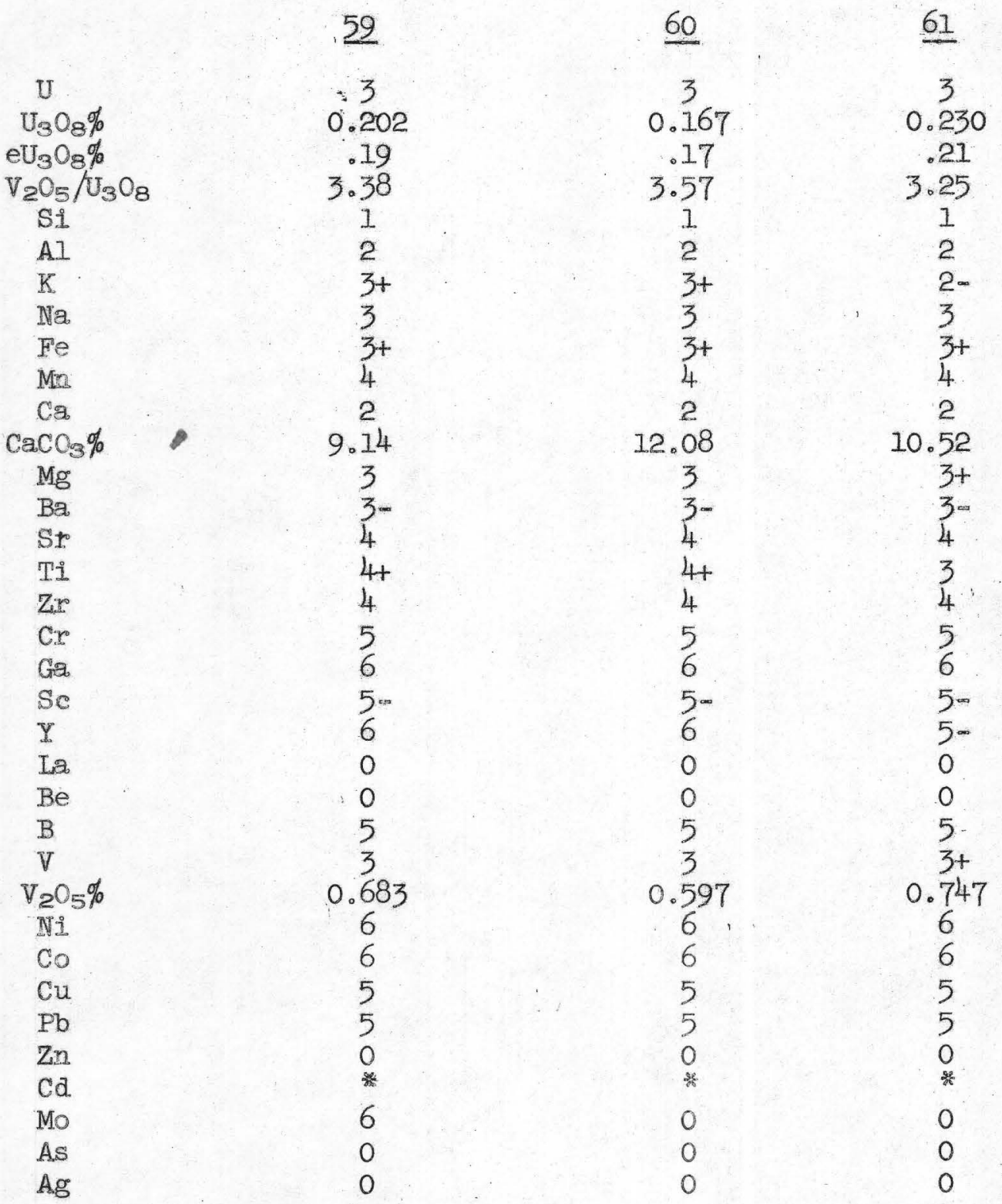

59 Cove no. I mine (PMS-18-51, D) T. 9 No, R. 7 Wo, Navajo M. (not surveyed)

60 Cove no. 2 mine (PNS-19-5I, D) T. 9 No, R. 7 Wo, Navajo M. (not surveyed)

61 Cove no. 4 mine (PMS-20-51, D) T. 9 N., R. 7 W., Navajo M. (not surveyed) 
Table 15K--Spectrographic analyses of mill-pulp samples of uranium ores, Slick Rock district

E.lements

Mines

\begin{tabular}{|c|c|c|c|c|c|c|}
\hline & 62 & 63 & 64 & 65 & 66 & 67 \\
\hline U & 3 & 3 & 4 & $2+$ & $2-$ & $3+$ \\
\hline $\mathrm{U}_{3} \mathrm{O}_{8} \%$ & 0.14 & 0.096 & 0.046 & $*$ & * & $\%$ \\
\hline $\mathrm{eU}_{3} \mathrm{O}_{8} \%$ & 0.14 & 0.093 & 0.044 & * & * & \% \\
\hline $\mathrm{V}_{2} \mathrm{O}_{5} / \mathrm{U}_{3} \mathrm{O}_{8}$ & 9.46 & 8.51 & 32.3 & * & * & * \\
\hline Si & 1 & 1 & 1 & 1 & 1 & 1 \\
\hline AI & 2 & 2 & 2 & $2+$ & $2+$ & $2+$ \\
\hline $\mathrm{K}$ & 3 & $3+$ & 0 & 0 & 0 & 0 \\
\hline $\mathrm{Na}$ & $3-$ & $4+$ & $3=$ & $4+$ & $4+$ & $4 t$ \\
\hline $\mathrm{Fe}$ & 3 & 2. & $3+$ & 2 & 2 & 2 \\
\hline $\mathrm{Mn}$ & 4 & 4 & $4=$ & 4- & 4 & 4 \\
\hline $\mathrm{Ca}$ & 2 & 2 & $3+$ & $2-$ & $3+$ & 3 \\
\hline $\mathrm{CaCO}_{3} \%$ & 7.9 & 3.5 & 2.4 & $*$ & 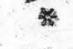 & * \\
\hline $\mathrm{Mg}$ & 3 & 3 & $3+$ & $3-$ & $3-$ & $3-$ \\
\hline $\mathrm{Ba}$ & 3- & 3 & $3-$ & $2-$ & 3 & $4+$ \\
\hline Sr. & 4 & 5 & 4 & 3 & 4 & $4=$ \\
\hline Ti & $4+$ & 3 & $4+$ & 4 & $4+$ & 4 \\
\hline $\mathrm{Zr}$ & 4 & 4 & 4 & 5 & 4- & 4 \\
\hline $\mathrm{Cr}$ & 5 & 5 & $5-$ & 5 & $5+$ & $5+$ \\
\hline Gi & 0 & 6 & 0 & $5-$ & $5-$ & 0 \\
\hline Se & 5- & 5 & 0 & 0 & 0 & 0 \\
\hline$Y$ & $5-$ & 5 & 5 & 5 & 5 & 0 \\
\hline Lक & 0 & 0 & 0 & 0 & 0 & 0 \\
\hline $\mathrm{Be}$ & 0 & 0 & 0 & 6 & 0 & 0 \\
\hline B & 5 & 5 & $5-$ & 0 & 0 & $5-$ \\
\hline V & $3+$ & 3 & $3+$ & 2 & 2 & $2-$ \\
\hline $\mathrm{V}_{2} \mathrm{O}_{5} \%$ & 1.33 & 0.82 & 1.67 & * & * & * \\
\hline $\mathrm{Ni}$ & 6 & 5 & 6 & 4 & 4 & 0 \\
\hline Co & 6 & 6 & 6 & $4-$ & 4 & 0 \\
\hline $\mathrm{Cu}$ & 4 & 5 & 3 & $5+$ & 5 & $4=$ \\
\hline $\mathrm{Pb}$ & 4 & 5 & $5+$ & $3+$ & 3 & 4 \\
\hline $\mathrm{Zn}$ & 4 & 4 & 4 & $4-$ & $4-$ & 0 \\
\hline $\mathrm{cd}$ & * & * & * & 4 & $4-$ & 0 \\
\hline Mo & $6+$ & $5+$ & 5 & $5-$ & $5+$ & 5 \\
\hline As & 0 & 4 & 0 & 0 & 0 & 0 \\
\hline $\mathrm{Ag}$ & 5 & $<6\left(" \operatorname{Tr}^{\prime \prime}\right)$ & 5 & 0 & 0 & 0 \\
\hline
\end{tabular}

62 Mucho Grande (PMS-12-51, D) sec. 1, T. 42 N., R. 18 W., N.M.P.M.

63 Parrot (PMS-1-51, D) sec. 26, T. 43 N., R. 18 W. N.M.P.M.

64 Sara M. (PMS -58.51, D) sec. 26, T. 43 N., R. 18 W., N.M.P.M.

65 Charles T. No. 2 (GS-105-51, W) sec. 10, T. 43 No, R. 19 W., N.M.P.M.

66 Charles T. No. 2 (GS-104-51, W) sec. 10, T. 43 No, R。 19 W., N.M.P.M.

67 Charles T. No. $2(\mathrm{GS}-50-50, \mathrm{~W})$ sec. 10, T. 43 N., R. 19 W., N.M.P.M. 
Table $15 K_{0}-$-Continued

\section{Elements}

\section{6}

\begin{tabular}{|c|c|c|c|c|c|}
\hline & 68 & 69 & 70 & 71 & 프 \\
\hline $\begin{array}{c}\mathrm{U} \\
\mathrm{U}_{3} \mathrm{O}_{8} \%\end{array}$ & $3-$ & $3-$ & $3+$ & $3-$ & $3+$ \\
\hline $\mathrm{eU}_{3} \mathrm{O}_{8} \%$ & * & * & * & $*$ & \\
\hline $\mathrm{V}_{2} \mathrm{O}_{5} / \mathrm{U}_{3} \mathrm{O}_{8}$ & * & $*$ & $\%$ & \% & \\
\hline Si & 1 & 1. & 1 & 1 & 1 \\
\hline A.1 & $2+$ & $2+$ & $2+$ & . $2+$ & $2+$ \\
\hline $\mathrm{K}$ & 0 & 0 & 0 & 0 & \\
\hline $\mathrm{Na}$ & $4+$ & $4+$ & $4+$ & $4+$ & \\
\hline $\mathrm{Fe}$ & 2 & $2-$ & 2 & $2-$ & \\
\hline Mn & 40 & $4-$ & 4 & 4 & \\
\hline $\mathrm{Ca}$ & $3+$ & $3+$ & $2-$ & $3+$ & 3 \\
\hline $\mathrm{CaCO}_{3} \%$ & * & * & w & * & \\
\hline $\mathrm{Mg}$ & $3+$ & 3 & 3 & 3 & 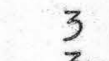 \\
\hline $\mathrm{Bz}$ & 3 & 4 & $4+$ & $4+$ & \\
\hline Sr $r$ & 4 & 4 & 4 & 4 & \\
\hline TI & 4 & $4+$ & 4 & 4 & \\
\hline$Z x$ & 5 & $5+$ & 5 & $5+$ & \\
\hline$C x$ & 5 & 5 & $5+$ & 5 & \\
\hline $\mathrm{G} \approx$ & 5 & 5 & 5 & $5-$ & \\
\hline $\mathrm{Sc}$ & 0 & 0 & 0 & 0 & \\
\hline$\Psi$ & 0 & 0 & 0 & 0 & \\
\hline La & 0 & 0 & 0 & 0 & \\
\hline $\mathrm{Be}$ & 6 & 6 & 6 & 6 & \\
\hline B & 0 & 0 & 0 & 0 & \\
\hline V & $2-$ & 2 & 2 & 2 & \\
\hline $\mathrm{V}_{2} \mathrm{O}_{5} \%$ & * & * & * & * & \\
\hline $\mathrm{Ni}$ & 4 & 4 & 4- & $4-\infty$ & \\
\hline $\mathrm{Co}$ & 4 & 4 & 4. & 4 & \\
\hline $\mathrm{Cu}$ & 5 & 4 & 4 & 4 & \\
\hline $\mathrm{Pb}$ & 3 & 3 & 3 & 3 & \\
\hline $\mathrm{Zn}$ & 0 & 0 & $4 \infty$ & 40 & \\
\hline $\mathrm{cd}$ & $5+$ & $4=$ & $4-$ & $4 \omega$ & \\
\hline Mo & $5-$ & $4-$ & $4-$ & 4- & \\
\hline As & 0 & 0 & 0 & 0 & \\
\hline $\mathrm{Ag}$ & 0 & 6 & 0 & $6-$ & \\
\hline
\end{tabular}

68 Michael Bray (GS-106-5I, W) sec. 16, T. 43 N., R. 19 W., N.M.P.M.

69 Radium no. 6 (GS-109-51, W) sec.9, T. 43 N., R. 19 W., N.M.P.M.

70 Radium no. 7, high grade, $($ GS $-111-51, W)$ sec. 8, T. 43 N., R. 19 W., N.M.P.M。

71 Radium no. 7, low grade, $(\operatorname{GS}-110-51, W)$ sec. 8, T. 43 N., R. 19 W., N.M.P.M.

72 Radium no. 8, (GS-51-50,W) sec。 8, T. 43 No, R. 19 W. N.M.P.M. 
Table 15K.--Continued.

\section{E.lements}

\begin{tabular}{|c|c|c|c|c|c|}
\hline & 73 & 74 & 75 & 76 & 77 \\
\hline U & 3 & 3 & 3 & 3 & , \\
\hline $\mathrm{U}_{3} \mathrm{O}_{8} \%$ & * & * & * & 0.11 & 0.26 \\
\hline $\mathrm{eU}_{3} \mathrm{O}_{8} \%$ & \% & * & * & 0.097 & 0.28 \\
\hline $\mathrm{V}_{2} \mathrm{O}_{5} / \mathrm{U}_{3} \mathrm{O}_{8}$ & * & $*$ & * & 5.09 & 4.50 \\
\hline $\mathrm{Si}$ & 1 & 1 & 1 & 1 & 1 \\
\hline Al & $2+$ & $2+$ & $2+$ & 2 & 2 \\
\hline $\mathrm{K}$ & 0 & 0 & 0 & 3 & 2. \\
\hline $\mathrm{Na}$ & $4+$ & $3-$ & $3-$ & 3 & 3 \\
\hline $\mathrm{Fe}$ & 2. & $2-$ & 2 & 2 & $3+$ \\
\hline$M n$ & 4 & 4 & 4 & 4 & $4+$ \\
\hline $\mathrm{Ca}$ & $3+$ & $3+$ & $2-$ & $2-$ & 2 \\
\hline $\mathrm{CaCO}_{3} \%$ & $\%$ & $*$ & * & 3.4 & 13.1 \\
\hline $\mathrm{Mg}$ & 3 & 3 & $3+$ & $3+$ & $2-$ \\
\hline $\mathrm{Ba}$ & $3-$ & $3-$ & 3 & 3 & 3 \\
\hline Sr & 4 & 4 & $4+$ & 4 & 4 \\
\hline Tí. & 4 & $4+$ & $4+$ & 3 & 3 \\
\hline $\mathrm{Zr}$ & 5 & $5+$ & $5+$ & 4 & 4 \\
\hline $\mathrm{Cr}$ & $4-$ & $4-$ & 4 & 5 & 5 \\
\hline $\mathrm{Ga}$ & $5-$ & 5 & 6 & 6 & 6 \\
\hline Sc & 0 & 0 & 0 & 5 & $5-$ \\
\hline$Y$ & 0 & 0 & 0 & 5 & - \\
\hline La & 0 & 0 & 0 & 5 & 0 \\
\hline $\mathrm{Be}$ & 6 & 0 & 0 & $6-$ & 0 \\
\hline B & 0 & 0 & 0 & 5 & 5 \\
\hline V & 2- & 2 & 2 & 3 & \\
\hline $\mathrm{V}_{2} \mathrm{O}_{5} \%$ & * & $*$ & * & 0.56 & 1.18 \\
\hline $\mathrm{Ni}$ & 3 & 4 & 4 & 6 & $6+$ \\
\hline Co & $4-$ & 4 & 4 & 6 & 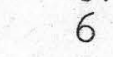 \\
\hline $\mathrm{Cu}$ & $3-$ & $4+$ & 4 & 5 & 5 \\
\hline $\mathrm{Pb}$ & 3 & 3 & 3 & 5 & \\
\hline $\mathrm{Zn}$ & 0 & 0 & 0 & 0 & \\
\hline$c d$ & $5+$ & 4. & $4-$ & * & $\%$ \\
\hline Mo & $5+$ & 5 & 5 & $5-$ & - \\
\hline $\mathrm{As}$ & 0 & 0 & 0 & 0 & \\
\hline $\mathrm{Ag}$ & $5-$ & $5-$ & $5-$ & 0 & \\
\hline
\end{tabular}

73 Cougar, high grade, (GS $-94-51$, W) sec.23, T. 44 N., R. 19 W., N.M.P.M.

74 Cougar, medium grade, (GS-96-51, W) sec。23, T. 44 N。, R。 19 W., N.M.P.M.

75 Cougar, low grade, (GS-95-5I, W) sec。23, T。 44 N., R。 19 W。, N.M.P.M。

76 Happy Ja.ck, (PMS-24-5I, D) sec. $7, T .44$ N。, R. 19 W。, N.M.P.M。

77 Empire group (PMS-39-51, D) sec. 12, T. 44 No, R。 26 W., N.M.P.M. 
Table 15L--Spectrographic analyses of mill-pulp samples of uranium ores, Thompsons and eastern Green River districts

Elements

Mines

$\underline{78}$

79

80

$\underline{81}$

$\underline{82}$

U

3
0.15
0.15
3.98

3

0.26

$\mathrm{eU}_{3} \mathrm{O}_{8} \%$

0.23

$\mathrm{V}_{2} \mathrm{O}_{5} / \mathrm{U}_{3} \mathrm{O}_{8} \quad 3.98$

Si

A.l.

1

6.66

1.

2-

K

$2-$

Na

3

0

$\mathrm{Fe}$

$\mathrm{Mn}$

4

Ca

$\mathrm{CaCO}_{3} \%$

$\frac{2-}{4}$

3-

2-

$4-$

3
0.12

4

0.11

10.98

1

2

0

3

$2-$

0.3

$\mathrm{Mg}$

$\mathrm{Ba}$

$\mathrm{Sr}$

Ti

$\mathrm{Zr}$

3
1.4

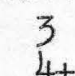

3

3

4.

$4+$

4

$5+$

Cr.

0

Sc

, 0

$Y$

0.

5

0

La

5

$\mathrm{Be}$

0

B

$\mathrm{V}$

0

6

5

2

$\mathrm{V}_{2} \mathrm{O}_{5} \%$

Ni

Co

$\mathrm{Cu}$

$\mathrm{Pb}$

$\mathrm{Zn}$

Cd.

Mo

As

$\mathrm{Ag}$

5
3

0.61

5

1.73

5

5

5

5

1. $4^{3+}$

0.07

0.04

4.00

1

2-

0.

$3-$

$$
3
$$

$3+$

0.08

0.071

0.59

1

2

2

$3+$

3

$4+$

4

5

6

0

5

0

0

5

2

1.36

$$
3
$$

$4+$

5

4

5-

0

0

5

0

0

5-

3

0.28

5

5

5

5
6

4

3

2

2

11.4

$3+$

4

4

3

$5+$

5

5

5

5

6

5
4

0.05

5

5
5

5

4

$5-$

4

4

6

< ${ }^{4}$ ("Tr")

0.

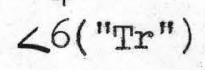

5

4.

4

5

0

Thompsons district:

78 Lena 16 (PMS-59-5I, D) T。24 S. R.20 E。, (not surveyed).

79 Cactus Rat, high grade, (PMS $-47-51, \mathrm{D})$ sec。33, T. 22 S., R. 22 E。, S.L.P.M.

80 Cactus Rat, low grade, (PMS-46-51, D) sec.33, T. $22 \mathrm{~S}$, , R. $22 \mathrm{E}$, S.I.P.M.

81 McCoy no. 4 (PMS-28-51, D) sec。26, T. 22 S., R。22 E., S.L.P.M。 Eastern Green River district:

82 Klondike (PMS -57-51, D) sec. 13, T。 25 S., R。20 E., S.L.P.M. 
Table $15 \mathrm{M}_{0}$--Spectrographic analyses of mill-pulp samples of uranium ores, Uravan and northern Bull Canyon districts.

Elements

Mines

$\underline{83}$

84

85

$\underline{86}$

$\mathrm{U}$
$\mathrm{U}_{3} \mathrm{O}_{8} \%$

$\mathrm{V}_{2} \mathrm{O}_{5} / \mathrm{U}_{3} \mathrm{O}_{8}$

$\mathrm{Si}$

A.

4- (?)

$\mathrm{K}$

$\mathrm{Na}$

*

3

3
$*$
$*$
$*$

1

$\frac{1}{2}$

2

$4+$

$\mathrm{Fe}$

$\mathrm{Mn}$

2

$\mathrm{Ca}$

$\mathrm{CaCO}_{3} \%$

$3+$

$\mathrm{Mg}$

$\mathrm{Ba}$

Sr

Ti

Zro

$\mathrm{Cr}$

Ga

$\mathrm{Sc}$

I

La

$\mathrm{Be}$

B

$\mathrm{V}$

$\mathrm{V}_{2} \mathrm{O}_{5} \%$

IVI

Co

$\mathrm{Cu}$.

$\mathrm{Pb}$

$\mathrm{Zn}$

ca.

MO

As

Ag

\section{$3-$}

$4+$

$4-$

4

5

5

5-

0

0

0

0

0

3

s

3-

4

$5+$

3.

$5+$

$5=$

0

0

$3 \quad 3$

* * *

* *

I

$2+$

0

0

2

$4 \infty$

4

*

1

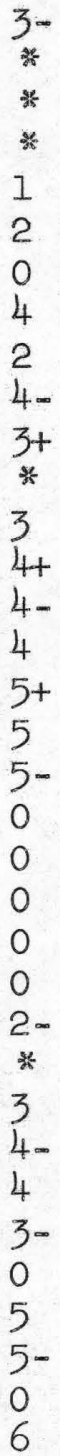

$2 \quad 2$

$0 \quad 0$

$\begin{array}{ll}0 & \\ 4 & 4\end{array}$

$2-$

4

$3+$

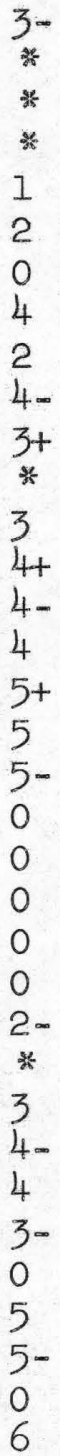

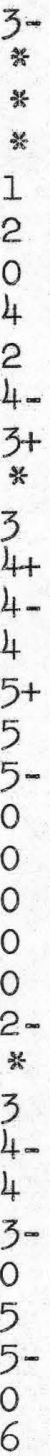

$2 \infty$

3

$5 \infty$

3

$4+$

4

4

5

$5+$

$5-$

0

0

0

0

0

2

3

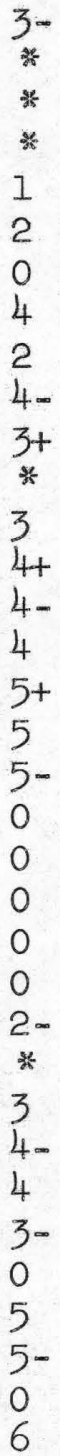

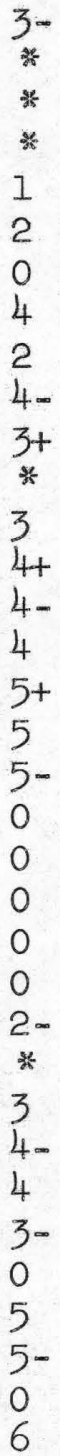

4

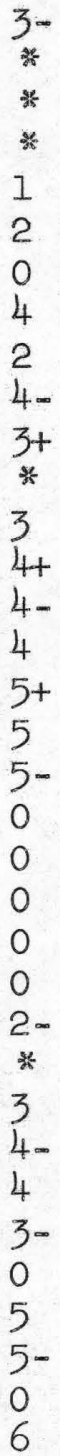

5

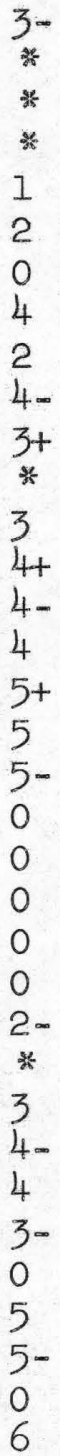

0

0

0

0

$5-$

2

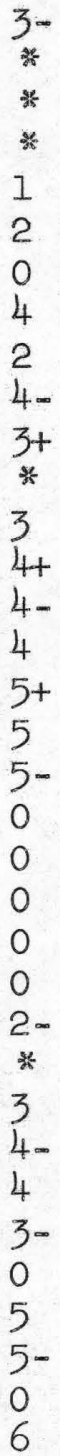

0

0

4

$4+$

0

0

0

0

0

Uravan district:

83 Bitter Creek (GS-97-5I, W) sec. I, T. 46 N., R. 17 W., N.M.P.M.

84 Long Park no. 10 (GS-39-50, W) sec. 27, T. 47 N, , R. 17 W., N.M.P.M.

85 Long Park no. 6 (GS-100-51, W) sec. 27, T. 47 N., R. 17 W., N.M.P.M.

86 Black Dinah (GS-102-5I, W) sec. 28, T. 47 N., R. 17 W., N.M.P.M. 
Table 15M。--Continued.

$\mathrm{U}_{3} \mathrm{O}_{8} \%$

$\mathrm{eU}_{3} \mathrm{O}_{8} \%$

$\mathrm{V}_{2} \mathrm{O}_{5} / \mathrm{U}_{3} \mathrm{O}_{8}$

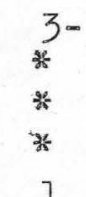

A]

$$
\mathrm{K}
$$

$\mathrm{Na}$

Fe

$\mathrm{Nn}$

Ca

$\mathrm{CaCO}_{3} \%$

$\mathrm{Mg}$

Ba

Sr

Ti.

$\mathrm{Zr}$

$\mathrm{Cr}$

Ga.

Sc

Y

L2.

$\mathrm{Be}$

B

$\mathrm{V}$

$\mathrm{V}_{2} \mathrm{O}_{5} \%$

$\mathrm{Ni}$

Co

$\mathrm{Cu}$

$\mathrm{Pb}$

$\mathrm{Zn}$

cd

Mo

A.s

$\mathrm{Ag}$
$3-$
$*$
$*$
$*$

2

0

0

2-

4

4

$*$

$3+$

3

$5-$

$4+$

$5+$

5

0

0

$5-$

0

0

5

2

0

0

5-

0

0

0

0

0

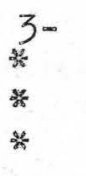

1

$2+$

0

4

$2-$

$4-$

$3+$

3

$4+$

4

5

5

$5=$

0

6

0

0

0

\%

4

4.

5

$3-$

0

$5+$

5 -

0

0

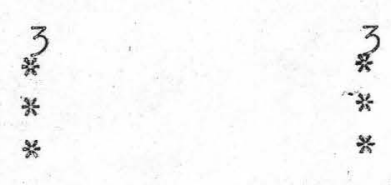

11

2+ $2+$

$0 \quad 0$

$4+\quad 4$

$20 \quad 2$

3+

$30 \quad 3+$

$5 \quad 4+$

$4 \quad 4$

$4-\quad 5-$

$5+\quad 5+$

0 5-

0 0

5- 0

$0 \quad 0$

$0 \quad 0$

$5 \div 0$

2 2-

$0 \quad 4$

$0 \quad 0$

4.5

$4-3-$

0 o

$0 \quad 5$

$0 \quad 5$

$0 \quad 0$
3

0
0
0
0
2.
4
0
5
$3-$
5
5
0
0

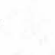

$+$

4

$+$

$4+$

$+$

Uravan district:

87 Coloradium (GS-47-50, W) sec.21, T. 47 N., R. 17 W., N.M.P.M.

88 Production (GS-101-51, W) sec.21, T. 47 N., R. 17 W., N.M.P.M.

89 Mill no. I (GS $-48-50$, W) sec. 33, T. 48 N., R。 17 W., N.M.P.M. Northern Bull Canyon district:

90 Hummer, (GS-103-51, W) sec. 21, T. 46 N., R. 17 W., N.M.P.M. 
Table 15N.--Spectrographic analyses of mill-pulp samples of uranium ores, White Canyon district

Elements

\section{Mines}

\begin{tabular}{|c|c|c|c|c|}
\hline & 91 & 92 & 93 & 24 \\
\hline$U$ & 3 & 4 & 3 & \\
\hline $\mathrm{U}_{3} \mathrm{O}_{8} \%$ & 0.13 & 0.07 & 0.22 & 0.11 \\
\hline $\mathrm{eU}_{3} \mathrm{O}_{8} \%$ & 0.26 & 0.13 & 0.30 & \\
\hline $\mathrm{Cu} / \mathrm{U}_{3} \mathrm{O}_{8}$ & * & 56.9 & 9.11 & 13.74 \\
\hline $\mathrm{V}_{2} \mathrm{O}_{5} / \mathrm{U}_{3} \mathrm{O}_{8}$ & 0.39 & 1.14 & * & \\
\hline Si & 1 & 1 & 1 & \\
\hline Al & 2 & 20 & 2 & \\
\hline $\mathrm{K}$ & 2 & 0 & $2-$ & \\
\hline$N a$ & 3 & 40 & 3 & \\
\hline $\mathrm{Fe}$ & $3+$ & 2 & 2 & 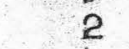 \\
\hline $\mathrm{Mn}$ & 5 & 4 & 4 & \\
\hline Ca: & 3 & $3+$ & $3 \infty$ & $3-$ \\
\hline $\mathrm{CaCO}_{3} \%$ & 0.26 & 2.1 & 0.29 & 1.1 \\
\hline $\mathrm{Mg}$ & 3 & $4+$ & 3 & \\
\hline $\mathrm{Bz}$ & 3 & $4+$ & 3 & \\
\hline $\mathrm{Sr}$ & 4 & 5 & $4-$ & \\
\hline Ti & 3 & 4 & 3 & \\
\hline $\mathrm{Zr}$ & 4 & $4-\infty$ & 4 & \\
\hline $\mathrm{Cr}$ & 5 & $5 \infty$ & $5-$ & \\
\hline GQ & $6+$ & 0 & 6 & \\
\hline Se & 5 & $5+$ & 5 & \\
\hline$\Psi$ & 5 & 4. & 4 & \\
\hline La & 5 & 5 & 5 & \\
\hline $\mathrm{Be}$ & 6 & 0 & 6 & \\
\hline B & 5- & 5- & $5-$ & \\
\hline V & 4 & 4 & 4 & \\
\hline $\mathrm{V}_{2} \mathrm{O}_{5} \%$ & 0.05 & 0.08 & * & \\
\hline $\mathrm{Ni}$ & 5 & $5+$ & 5 & \\
\hline Co & 5 & $5+$ & 5 & \\
\hline $\mathrm{Cu}$ & 4 & 2 & 2 & \\
\hline Cu\% & * & 3.98 & 2.03 & 1.2 \\
\hline $\mathrm{Pb}$ & $5+$ & 4. & $4=$ & \\
\hline $\mathrm{Zn}$ & 4 & $4+$ & 0 & \\
\hline$c a$ & * & $*$ & * & \\
\hline Mo & $4+$ & 4 & 5 & \\
\hline As & 0 & 0 & 0 & \\
\hline $\mathrm{Ag}$ & 0 & 6 & $4=$ & \\
\hline
\end{tabular}

91 Noteh (PMS $-56-51$, D) sec. 7, T. 35 S., R. 20 E., S.L.P.M. (survey not shown on map)

92 Hideout (PMS $-54-51$, D) 1at. $37^{\circ} 39^{\circ} \mathrm{N}, 10 n g .110^{\circ} \mathrm{O} 2^{\prime} \mathrm{W}$.

93 Posey, high grade, (PMS $-49-51$, D) lat. $37^{\circ} 34^{\prime}$, nd long. $110^{\circ} 20^{\prime} \mathrm{W}$.

94 Posey, low grade, (PMS $-48-51$, D) lat. $37^{\circ} 34^{\prime} \mathrm{N}$, long. $110^{\circ} 20^{\prime} \mathrm{W}$. 
Table 15N.--Continued.

Elements

\begin{tabular}{|c|c|c|c|c|c|}
\hline & 25 & 96 & 27 & 98 & 99 \\
\hline U & 3 & 3 & $3+$ & $3+$ & $4+$ \\
\hline $\mathrm{U}_{3} \mathrm{O}_{8} \%$ & 0.27 & 0.16 & * & $*$ & $\%$ \\
\hline $\mathrm{eU}_{3} \mathrm{O}_{8} \%$ & 0.27 & 0.25 & \% & * & * \\
\hline $\mathrm{Cu} / \mathrm{U}_{3} \mathrm{O}_{8}$ & 2.84 & 2.86 & * & * & $*$ \\
\hline $\mathrm{V}_{2} \mathrm{O}_{5} / \mathrm{U}_{3} \mathrm{O}_{8}$ & * & * & $*$ & $*$ & $*$ \\
\hline Si & 1 & 1 & 1 & 1 & 1 \\
\hline AI. & 2 & 2 & 2 & 2 & 2 \\
\hline $\mathrm{K}$ & 0 & 0 & 0 & 0 & 0 \\
\hline N\% & 4 & 4 & 0 & 0 & 0 \\
\hline $\mathrm{Fe}$ & 2 & 2 & 2 & 2 & 2. \\
\hline Mn & 4 & $5 t$ & $5+$ & $5+$ & 4- \\
\hline $\mathrm{Ca}$ & 4 & 4 & $3-$ & 3 & 3 \\
\hline $\mathrm{CaCO}_{3} \%$ & 0.20 & 0.57 & * & * & * \\
\hline $\mathrm{Mg}$ & 3 & 3 & $4+$ & $3-$ & 3 \\
\hline $\mathrm{Ba}$ & $3=$ & $3-$ & $4-$ & $4=$ & 4 \\
\hline Sr & 4 & 4 & 4. & 4 & 4 \\
\hline Ti & 3 & 3 & $3=$ & $4+$ & 3- \\
\hline $\mathrm{Zr}$ & 4 & 4 & 5 & $4=$ & $4 \infty$ \\
\hline $\mathrm{Cr}$ & 5 & 5 & $5-$ & 5 & 5 \\
\hline G9 & 6 & 6 & 0 & 0 & 0 \\
\hline se & 5 & 5 & $6+$ & $5-$ & $6+$ \\
\hline$\Psi$ & 5 & 5 & 5 & 5 & $5=$ \\
\hline La & 5 & 5 & 0 & 0 & 0 \\
\hline $\mathrm{Be}$ & 6 & 6 & 6 & 6 & 6 \\
\hline B & 5 & 5 & 0 & 0 & 0 \\
\hline v & 4. & $5+$ & $4 \infty$ & 4 & $4 \infty$ \\
\hline $\mathrm{V}_{2} \mathrm{O}_{5} \%$ & * & * & * & * & * \\
\hline $\mathbb{N i}$ & $5+$ & 5 & 3 & $3-$ & 4 \\
\hline Co & $5+$ & 5 & 3 & 3 & $3-$ \\
\hline $\mathrm{Cu}$ & 3 & 3 & 4 & $3+$ & $3+$ \\
\hline Cu\% & 0.76 & 0.47 & ซ & * & * \\
\hline $\mathrm{Pb}$ & 5 & 5 & $3+$ & 3 & $3+$ \\
\hline $\mathrm{Zn}$ & 4 & 4 & 4 & 4 & $4-\infty$ \\
\hline $\mathrm{cd}$ & * & * & 0 & 0 & 0 \\
\hline Mo & 4 & 4 & $4 \infty$ & 4 & 5 \\
\hline As & 0 & 4 & $4+$ & $4+$ & $4+$ \\
\hline $\mathrm{Ag}$ & 6 & 6 & 0 & 6 & 0 \\
\hline
\end{tabular}

95 Fry no. 4, high grade, (PMS $-43-51$, D) lat. $37^{\circ} 34^{\prime} \mathrm{N}$.

96 Fry no. 4, low grade, (PMS $-42-51, \mathrm{D})$ lat. $37^{\circ} 34^{\prime} \mathrm{N}$, long. $110^{\circ} 07^{\circ} \mathrm{W}$.

97 Happy Jack, high grade, (GS $-87-51$, W) 1at. $37^{\circ} 47^{\circ} \mathbb{N}$. , long. $110^{\circ} 19^{\prime} W$.

98 Happy Jack, intermediate grade, (GS-86-51, W) lat. $37^{\circ} 47^{\circ} \mathbb{N}$, long. $110^{\circ} 19^{\circ} \mathrm{W}$.

99 Happy Jack, low grade, (GS-85-51, W) lat. $37^{\circ} 47^{\circ} \mathrm{N}$., long. $110^{\circ} 19^{\prime} \mathrm{W}$. 
Table 15-0.--List of mill-pulp samples from mines in pre-Morrison formations

\section{Grants district}

\section{Formation}

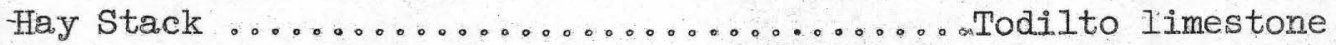

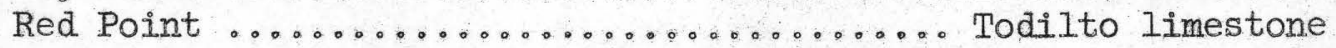

Green River district

Klondike Chinle formation

Gypsum Va.11ey district

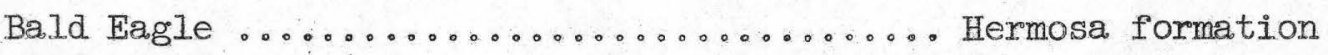

Henry Mountains district

Poison Springs no. $2 \ldots \ldots \ldots \ldots \ldots \ldots$ Shinarump conglomerate House Rock district

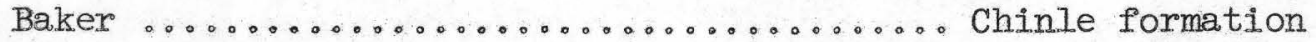

Monticello district

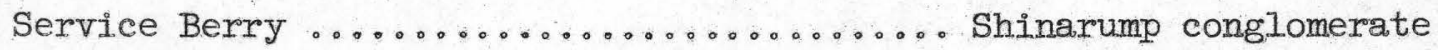

Monument Valley district

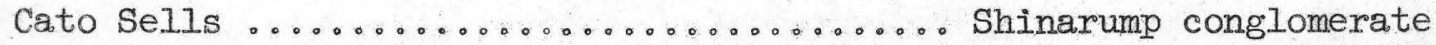
Monument no. $2 \ldots \ldots \ldots \ldots \ldots \ldots \ldots$ Shinarump conglomerate

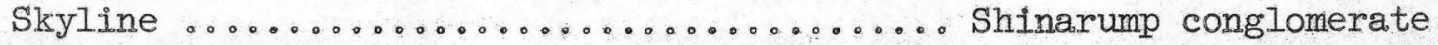

San Rafael district

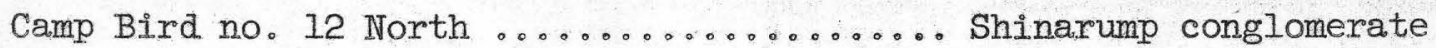
Camp Bird no. 12 South ................ Shinarump conglomerate Camp Bird no. $13 \ldots \ldots \ldots \ldots \ldots \ldots$ Shinarump conglomerate Dixty Devil nos. 3 and $4 \ldots \ldots \ldots \ldots \ldots$ Shinarump conglomerate Lucky strike no. $2 \ldots \ldots \ldots \ldots \ldots \ldots \ldots \ldots$ Shinarump conglomerate

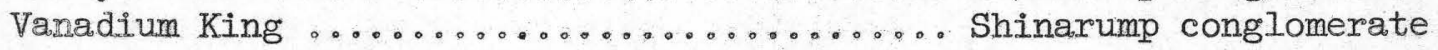

\section{White Canyon district}

Fry no. $4 \ldots \ldots \ldots \ldots \ldots \ldots \ldots \ldots \ldots \ldots \ldots \ldots \ldots$ Shinarump conglomerate

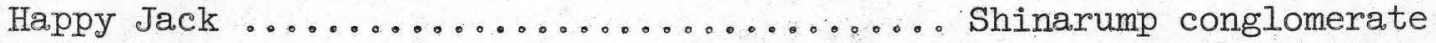
Hideout $\ldots \ldots \ldots \ldots \ldots \ldots \ldots \ldots \ldots$ Shinarump conglomerate

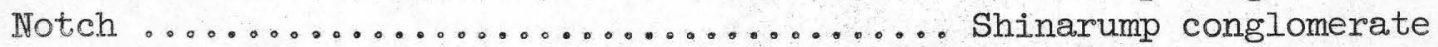
Posey $\ldots \ldots \ldots \ldots \ldots \ldots \ldots \ldots$ Shinarump conglomerate 